\title{
Human gene polymorphisms and their possible impact on the clinical outcome of SARS-CoV-2 infection
}

\author{
Seyed Mohammad Ali Hashemi ${ }^{1,2}$ - Marijn Thijssen ${ }^{3} \cdot$ Seyed Younes Hosseini ${ }^{1}$. Alijan Tabarraei ${ }^{4}$. \\ Mahmoud Reza Pourkarim ${ }^{3,5}$. Jamal Sarvari ${ }^{1,6}$
}

Received: 24 October 2020 / Accepted: 23 February 2021 / Published online: 2 May 2021

(c) The Author(s), under exclusive licence to Springer-Verlag GmbH Austria, part of Springer Nature 2021

\begin{abstract}
The SARS-CoV-2 pandemic has become one of the most serious health concerns globally. Although multiple vaccines have recently been approved for the prevention of coronavirus disease 2019 (COVID-19), an effective treatment is still lacking. Our knowledge of the pathogenicity of this virus is still incomplete. Studies have revealed that viral factors such as the viral load, duration of exposure to the virus, and viral mutations are important variables in COVID-19 outcome. Furthermore, host factors, including age, health condition, co-morbidities, and genetic background, might also be involved in clinical manifestations and infection outcome. This review focuses on the importance of variations in the host genetic background and pathogenesis of SARS-CoV-2. We will discuss the significance of polymorphisms in the ACE-2, TMPRSS2, vitamin D receptor, vitamin D binding protein, CD147, glucose-regulated protein $78 \mathrm{kDa}$, dipeptidyl peptidase-4 (DPP4), neuropilin-1, heme oxygenase, apolipoprotein L1, vitamin K epoxide reductase complex 1 (VKORC1), and immune system genes for the clinical outcome of COVID-19.
\end{abstract}

\section{Background}

In March 2020, the World Health Organization (WHO) declared a pandemic caused by an emerging coronavirus named severe acute respiratory syndrome coronavirus 2 (SARS-CoV-2). The pathogen rapidly surged across the globe, causing havoc on all continents and severely destabilizing healthcare systems. An infection with this virus

Handling Editor: William G Dundon.

Jamal Sarvari

sarvarij@sums.ac.ir; jamalsarvari@yahoo.com;

sarvarijamal@gmail.com

http://med.sums.ac.ir/departments/basic_sciences/

bacteriology-virology/staff $1 / \mathrm{dr}$.sarvari

Seyed Mohammad Ali Hashemi

hashemit71@gmail.com

Marijn Thijssen

marijn.thijssen@kuleuven.be

Seyed Younes Hosseini

hoseiniy@sums.ac.ir

Alijan Tabarraei

tabarraei@goums.ac.ir

Mahmoud Reza Pourkarim

mahmoudreza.pourkarim@kuleuven.be can cause a variety of mild to severe symptoms, which are collectively named coronavirus disease-2019 (COVID-19) [1]. SARS-CoV-2 is a member of the genus Betacoronavirus, family Coronaviridae. This enveloped virus has a positive single-stranded RNA genome with a length of 29.8 to $29.9 \mathrm{~kb}$, making it the largest amongst all human RNA viruses [2-4]. SARS-CoV-2 is primarily transmitted through respiratory droplets and contact routes [2, 5]. With unprecedented speed, multiple vaccines have recently been approved, and many others are currently under development

1 Department of Bacteriology and Virology, Shiraz University of Medical Sciences, Shiraz, Iran

2 Department of Microbiology, Golestan University of Medical Sciences, Gorgan, Iran

3 Laboratory for Clinical and Epidemiological Virology, Department of Microbiology, Immunology and Transplantation, Rega Institute for Medical Research, 3000 Leuven, Belgium

4 Infectious Diseases Research Center, Golestan University of Medical Sciences, Gorgan, Iran

5 Health Policy Research Centre, Institute of Health, Shiraz University of Medical Sciences, Shiraz, Iran

6 Gastroenterohepatology Research Center, Shiraz University of Medical Sciences, Shiraz, Iran 
to prevent COVID-19. However, with regard to antiviral drugs, specific treatments for SARS-CoV-2 are not yet available.

The course of disease can differ greatly among individuals, ranging from an asymptomatic infection to mild or severe disease and death. The mortality rate for SARSCoV-2 is still under debate and is affected by multiple variables [2, 5-7]. From the start of the COVID-19 pandemic, there have been numerous publications about the pathogenesis of the virus, but much still remains to be elucidated. For instance, it is still not clear why some people remain asymptomatic while others develop severe disease. Furthermore, viral respiratory infections are usually more serious in children than in adults, but for SARS-CoV-2 infection this seems to be reversed. Answering these questions and finding the factors that affect the virulence of SARS-CoV-2 will contribute to the development of suitable treatment strategies and better infection control.

Age is an important factor in the outcome of viral respiratory infections. During the Spanish flu pandemic in 1918, the mean death rate was high in people aged younger than five years, 20-40 years old, and older than 65 years [8]. Similarly, at the start of the H1N1 influenza pandemic in 2009, severe pneumonia was observed in 5- to 59-year-old individuals [9]. With other coronaviruses, such as SARS-CoV and human cronavirus-NL63 (HCoV-NL63), it has been observed that children are relatively resistant to infection, similar to the current observations for SARS-CoV-2 [10, 11].

It has been demonstrated that viral factors such as the number of viral particles in the inoculum, duration of exposure to the virus, and mutations in the virus genome can influence the severity and outcome of the disease [12]. Similarly, host factors such as health condition, age, gender, smoking, immune status, diabetes, hypertension, cardiovascular disease, chronic respiratory disease, cancer, and, more importantly, the genetic background, might determine the clinical manifestations and outcome of infection [13-17]. Based on the data, it appears that the genetic background of the host influences the severity of the infection and disease outcome $[18,19]$. In this review, we provide a comprehensive overview of the current data regarding host gene polymorphisms that might be associated with the pathogenesis and outcome of SARS-CoV-2 infection.

\section{Angiotensin-converting enzyme 1 and angiotensin-converting enzyme 2 polymorphisms}

The human ACE or ACE-1 gene is located on chromosome 17 q23.3 and is made up of 26 exons. It contains some polymorphisms including insertions (I) or deletions (D) as well as a repetitive sequence of 287 base pairs of Alu sequence in intron 16 [20]. It has been reported that polymorphisms in this gene are associated with SARS-CoV infection outcome [21]. The serum level of ACE in people with the DD genotype is almost twice that of genotype II [22]. The D allele might affect renin-angiotensin pathway activity by increasing the serum or local level of ACE, leading to damage of the vascular endothelium and lung epithelium [23]. Studies have shown that some ACE polymorphisms are associated with Alzheimer's disease (the II and ID ACE genotypes), cardiovascular disease (DD), hepatitis $\mathrm{C}$ virus (HCV) infection (DD), and cancers (ACE A240T polymorphism) [24-29] (Table 1). Itoyama et al. found that the frequency of the D allele in SARS patients (with and without hypoxemia) was significantly higher than in healthy controls [21]. Also, they suggested that ACE-1 insertions/ deletions (I/D) could probably accelerate the development of pneumonia in SARS-CoV infection [21]. Another study in Caucasian individuals demonstrated that the presence of the $\mathrm{D}$ allele was accompanied by an increased rate of acute respiratory distress syndrome (ARDS) [30]. Yamamoto et al. reported that the frequency of SARS-CoV-2 infections and mortality strongly correlated with the ACE-1 I/D genotype, which might serve as a predictive marker for the severity of COVID-19 [31]. On the other hand, Chan et al. reported that in the Chinese population, the ACE I/D polymorphism was not associated with SARS-CoV infection [32] (Table 2). The reason for this discrepancy in the Chinese population is unknown, but it might be related to the lower frequency of the DD genotype and the $\mathrm{D}$ allele in the Chinese population than in people with a Caucasian background [30, 33].

Angiotensin-converting enzyme 2 (ACE-2) is a close homolog of ACE (or ACE-1), exhibiting 61\% amino acid similarity and $40 \%$ sequence identity. ACE- 2 acts as a carboxyl peptidase [34] and has been recognized as the main entry receptor for both SARS-CoV and SARS-CoV-2 through interaction with the spike (S) protein [35]. The ACE-2 gene is located on chromosome Xp22.2 and contains 18 exons [36]. This enzyme is anchored in the cell membranes as a type 1 integral membrane glycoprotein with a high expression level in lung, heart, artery, intestinal, and kidney tissues [37]. The primary role of ACE-2 is converting angiotensin II to angiotensin 1-7, but it also converts angiotensin I to angiotensin 1-9 [34]. Aberrant expression of ACE-2 has been associated with atherosclerosis, hypertension, heart failure, chronic kidney disease, and increased vascular permeability, facilitating respiratory system edema [38-43].

Entry of SARS-CoV-2 into target cells is facilitated by the $\mathrm{S}$ protein, which consists of two subunits, $\mathrm{S} 1$ and $\mathrm{S} 2$. The $\mathrm{S} 1$ subunit contains the receptor-binding domain (RBD), which interacts with the peptidase domain (PD) of the ACE-2 protein, and this is a critical step for entry of the virus into the host cell [44]. Therefore, genetic variations in the ACE-2 
sequence might alter the molecular interaction of the RBD and PD domains, which not only changes the host susceptibility to the virus but also influences the severity of the disease and the outcome of infection.

A recent investigation indicated that genetic variations and expression patterns of ACE-2 might reduce susceptibility to SARS-CoV-2 infection. Given that ACE-2 is located on sex chromosome $\mathrm{X}$, it could be related to the observed gender discrepancies in disease outcome. Srivastava et al. reported a significant positive correlation between ACE2 rs2285666 polymorphism and a lower frequency of infection and case-fatality rate in SARS-CoV-2 infection in the Indian population [45]. Moreover, it has been reported that three SNPs - K26R (rs4646116), M82I (rs267606406) and E329G (rs143936283) - are associated with higher binding affinity for the RBD domain of the $\mathrm{S}$ protein compared to wild-type ACE-2. This might result in increased susceptibility to SARS-CoV-2 infection [46]. In contrast, the I21T (rs 1244687367), E37K (rs146676783) and D355N (rs961360700) SNPs cause a significantly lower binding affinity and could decrease the susceptibility to infection [46]. Moreover, the hotspot N720D variant in the C-terminal collectrin-like domain of ACE-2 affects the ACE-2-TMPRSS2 complex and creates a favorable site for TMPRSS2 binding and cleavage, thus facilitating binding to the S protein and potentially promoting virus entry into the cell [47]. Molecular docking simulations have revealed that six ACE2 missense variants - I21T, A25T, K26R, E75G, T55A and E37K - increase binding affinity, while 11 variants - I21V, E35K, K26E, T27A, S43R, Y50F, N51D, N58H, K68E, E23K and M82I - decrease the affinity of ACE-2 for the RBD of the S protein [48]. Hashizume et al. reported that ACE-2 SNPs have a limited impact on the ACE-2-dependent cell entry of SARS-CoV-2 [49]. Furthermore, a large cohort study on an Italian population demonstrated no significant relationship between ACE-2 polymorphisms and the severity of COVID-19 [15] (Table 2).

Both SARS-CoV and human coronavirus NL-63 replication cause a reduction in the expression of the ACE-2 protein, which has been demonstrated to induce more-severe complications in SARS-CoV infection [50]. This reduction is caused by the inhibitory effect of the $S$ protein on ACE-2 expression in infected cells and might result in severe acute lung failure [50]. Hence, considering the protective function of ACE-2 in the tissues, SARS-CoV-2 infections might induce an imbalance in Ang II/Ang1-7 and consequently result in inflammation and hypoxia [51]. Another report has indicated that an increase in the concentration and/or expression of ACE-2 receptors in pediatric lung pneumocytes probably provides protection against severe clinical manifestations of SARS-CoV-2 infection [52]. It has been shown that the injection of the SARS-CoV S protein into mice leads to pulmonary failure. This effect was diminished by blocking the renin-angiotensin pathway [53]. Angiotensin II type I receptor (AT1R) is an important receptor that mediates vascular permeability, and its activation promotes severe acute pulmonary damage [54]. A study performed in mice demonstrated that the inhibition of AT1R reduces severe lung damage as well as pulmonary edema [53].

In addition to its involvement in coronavirus infection, ACE-2 has also been associated with other viral respiratory infections. For instance, Gu et al. reported that ACE-2 plays a considerable role in pulmonary damage related to respiratory syncytial virus (RSV) infection, which might be related to the high level of angiotensin II in the plasma [55]. Increased levels of angiotensin II could be the result of decreased ACE- 2 expression and could lead to severe lung damage by mediating AT1R during RSV infection [55]. Moreover, an association was observed between influenza virus infection and ACE-2 expression levels, which was different with various strains of influenza virus [56, 57]. Although some studies have focused on studying pulmonary pathology to evaluate the impact of these viruses, the molecular mechanisms by which one is predisposed to pulmonary damage are not completely explained by the effects of infection on the renin-angiotensin system (RAS) and ACE-2.

\section{Transmembrane protease serine 2 polymorphism}

The transmembrane protease serine 2 (TMPRSS2) gene, with a length of $43.59 \mathrm{kbp}$, is located on chromosome 21q22.3 and consists of 14 exons [58]. It encodes a transcript that is processed by alternative splicing to provide two mRNA variants of 3.25 and $3.21 \mathrm{~kb}$. The TMPRSS2 protein (492 amino acids) is a type II transmembrane serine protease that is expressed on the surface of different tissues/cells, including the small intestine, prostate, colon, salivary gland, and stomach [58]. TMPRSS2 upregulation has been demonstrated in some cancerous cells, and it promotes metastasis by proteolytic activation of hepatocyte growth factor (HGF), a pathway that is targeted by specific drugs [59]. Some polymorphisms in TMPRSS2 have been reported to be genetic risk factors for specific types of cancers and viral infections $[15,60]$. For instance, the TMPRSS2 M160V polymorphism increases the susceptibility to prostate cancer in Japanese men [60].

Recently, it was reported that polymorphisms in the TMPRSS2 gene might be involved in susceptibility to SARS-CoV-2 infection and COVID-19 outcome [15]. Proteolytic cleavage of the $\mathrm{S}$ protein by TMPRSS 2 at the S1/S2 boundary triggers S2-mediated fusion of the viral envelope and endosome membrane, which is a crucial step for the release of the ribonucleoprotein into the cytoplasm [35]. Expression of the TMPRSS2 gene is 







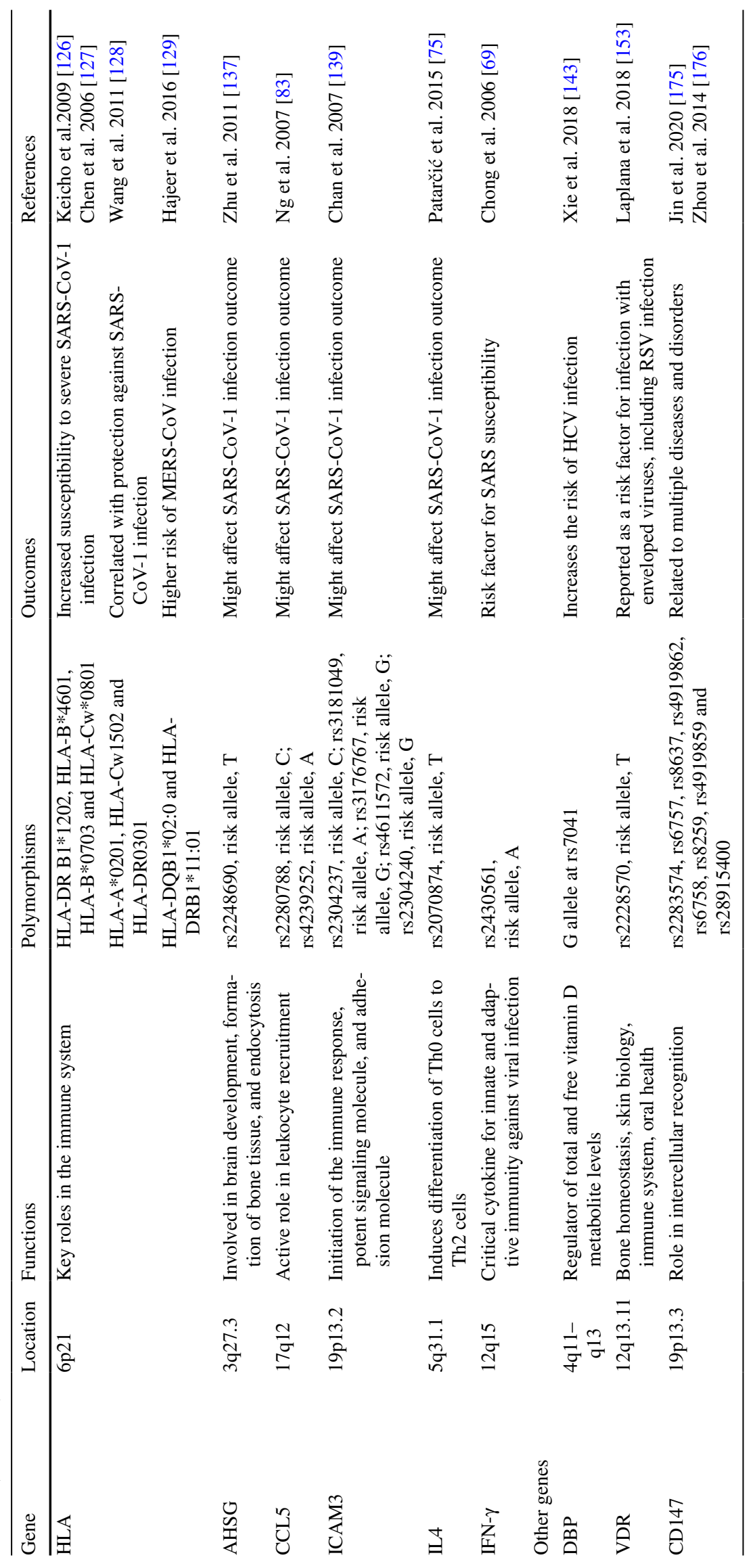


Table 2 Human genetic polymorphisms related to the outcome of infection with SARS-CoV-2

\begin{tabular}{|c|c|c|c|c|c|}
\hline Gene & Location & Functions & Polymorphisms & Outcomes & References \\
\hline \multicolumn{6}{|c|}{ Viral attachment and entry } \\
\hline \multirow[t]{3}{*}{ ACE2 } & \multirow[t]{3}{*}{$\mathrm{Xp} 22.2$} & \multirow[t]{2}{*}{$\begin{array}{l}\text { a) Converts angiotensin I } \\
\text { to angiotensin } 1-9\end{array}$} & rs2285666, & $\begin{array}{l}\text { Decreased infection and fatal- } \\
\text { ity rate }\end{array}$ & $\begin{array}{l}\text { Srivastava et al. } \\
2020[45]\end{array}$ \\
\hline & & & $\begin{array}{l}\text { rs } 4646116, \\
\text { rs267606406, } \\
\text { rs143936283 }\end{array}$ & Increased susceptibility & $\begin{array}{l}\text { Wang et al. } 2020 \\
\text { [46] }\end{array}$ \\
\hline & & $\begin{array}{l}\text { b) Converts angiotensin } \\
\text { II to angiotensin 1-7 }\end{array}$ & $\begin{array}{l}\text { rs961360700, } \\
\text { rs146676783, } \\
\text { rs1244687367 }\end{array}$ & Decreased susceptibility & $\begin{array}{l}\text { Wang et al. } 2020 \\
\text { [46] }\end{array}$ \\
\hline \multirow[t]{3}{*}{ TMPRSS2 } & \multirow[t]{3}{*}{$21 \mathrm{q} 22.3$} & \multirow{3}{*}{$\begin{array}{l}\text { Transmembrane serine } \\
\text { protease } \\
\text { that increases virus entry }\end{array}$} & $\begin{array}{l}\text { rs2070788, rs } 9974589, \\
\quad \text { rs7364083 }\end{array}$ & Increased susceptibility & $\begin{array}{l}\text { Asselta et al. } 2020 \\
\text { [15] }\end{array}$ \\
\hline & & & $\begin{array}{l}\text { rs77675406, rs713400, } \\
\quad \text { rs112657409, } \\
\text { rs11910678 }\end{array}$ & Increased susceptibility & $\begin{array}{l}\text { Senapati et al. } \\
2020 \text { [62] }\end{array}$ \\
\hline & & & $\begin{array}{l}\text { rs2070788, rs383510, } \\
\text { rs } 464397, \\
\text { rs469390 }\end{array}$ & Increased susceptibility & $\begin{array}{l}\text { Irham et al. } 2020 \\
{[63]}\end{array}$ \\
\hline \multicolumn{6}{|c|}{ Immune responses } \\
\hline \multirow[t]{2}{*}{ TLR3 } & \multirow[t]{2}{*}{$4 \mathrm{q} 35.1$} & \multirow[t]{2}{*}{$\begin{array}{l}\text { Sensor of double- } \\
\text { stranded RNA }\end{array}$} & rs73873710 & $\begin{array}{l}\text { Improved recognition of } \\
\text { SARS-CoV-2 dsRNA }\end{array}$ & \multirow[t]{2}{*}{$\begin{array}{l}\text { Teimouri et al. } \\
2020[140]\end{array}$} \\
\hline & & & $\begin{array}{l}\text { rs3775290, } \\
\text { rs3775291 }\end{array}$ & $\begin{array}{l}\text { Decreased recognition } \\
\text { ofSARS-CoV-2 dsRNA }\end{array}$ & \\
\hline IFIH1 & $2 \mathrm{q} 24.2$ & $\begin{array}{l}\text { Intracellular sensor of } \\
\text { viral RNA }\end{array}$ & rs1990760 & $\begin{array}{l}\text { Decreased susceptibility to } \\
\text { SARS-CoV-2 infection ( } \mathrm{T} \\
\text { allele) }\end{array}$ & Maiti. 2020 [118] \\
\hline CCR5 & $3 \mathrm{p} 21.31$ & Chemokine receptor & CCR5 $\Delta 32$ & $\begin{array}{l}\text { Increased susceptibility to } \\
\text { SARS-CoV-2 infection and } \\
\text { mortality }\end{array}$ & Panda. 2020 [74] \\
\hline IFNL4 & $19 \mathrm{q} 13.2$ & $\begin{array}{l}\text { Immune response to viral } \\
\text { infection }\end{array}$ & $\mathrm{rs} 368234815 \mathrm{TT} / \Delta \mathrm{G}$ & Higher viral loads & $\begin{array}{l}\text { Amodio et al. } 2020 \\
\text { [79] }\end{array}$ \\
\hline \multicolumn{6}{|l|}{ Other genes } \\
\hline DBP & $4 q 11-q 13$ & $\begin{array}{l}\text { Regulator of total and } \\
\text { free vitamin D metabo- } \\
\text { lite levels }\end{array}$ & rs7041 & $\begin{array}{l}\text { GT and TT genotype are posi- } \\
\text { tively and negatively related } \\
\text { to the rate of SARS-CoV-2 } \\
\text { infection and mortality, } \\
\text { respectively }\end{array}$ & $\begin{array}{l}\text { Karcioglu et al. } \\
2020[141]\end{array}$ \\
\hline DPP4 & $2 q 24.2$ & Serine exopeptidase & rs 13015258 & $\begin{array}{l}\text { Expression of key regulatory } \\
\text { genes related to internaliza- } \\
\text { tion of SARS-CoV-2 into } \\
\text { the cell }\end{array}$ & $\begin{array}{l}\text { Senapati et al. } \\
2020 \text { [62] }\end{array}$ \\
\hline VKORC1 & $16 \mathrm{p} 11.2$ & $\begin{array}{l}\text { Decreased vitamin K } \\
\text { level }\end{array}$ & 1639A (rs9923231) & $\begin{array}{l}\text { Associated with protection } \\
\text { against thrombotic complica- } \\
\text { tions of COVID-19 }\end{array}$ & $\begin{array}{l}\text { Janssen et al. } 2020 \\
\text { [217] }\end{array}$ \\
\hline
\end{tabular}

affected by androgen and estrogen hormones, which might partially explain the observed gender differences in disease severity [53, 57, 61]. A study in Italy demonstrated that some SNPs, including rs2070788, rs9974589, and rs7364083, were associated with a higher expression level of TMPRSS2 and played a considerable role in determining the severity of COVID-19 [15]. Moreover, four other polymorphisms - rs77675406, rs713400, rs112657409, and rs11910678 of TMPRSS2 - affect the expression of the TMPRSS2 gene [62]. Another study showed that four 
variants of TMPRSS2 - rs2070788, rs383510, rs464397 and rs469390 - which affect the expression of TMPRSS2 in lung tissue, had a higher frequency in European and American populations than in Asian populations. These observations might explain the relatively higher susceptibility of European and American populations to SARSCoV-2 infection [63] (Table 1). Furthermore, a recent report by Fuentes et al. demonstrated that synonymous variants of rs61735794 and rs61735792 were significantly associated with SARS-CoV-2 infection outcome [64].

Variations in the TMPRSS2 gene have also been associated with the outcome of other viral infections. For instance, Cheng et al. reported that rs 2070788 and rs 383510 polymorphisms were associated with higher susceptibility to H1N1 and H7N9 infection. Based on these findings, the authors suggest that people carrying these polymorphisms might have a higher risk of progression to severe disease [65].

\section{Immune system gene polymorphism}

The relationships between polymorphisms of the immune genes and the outcome of viral infections have always been a matter of concern. Considering the pivotal role of these genes in viral clearance and immunopathogenesis, polymorphisms in these regions are likely to affect the outcome of an uncharacterized disease like COVID-19 (Tables 1,2).

\section{Cytokines}

Cytokines are small proteins ( $\sim-20 \mathrm{kDa})$ that are important for cell signaling and include interleukins, chemokines, lymphokines, interferons, and tumour necrosis factors. In severe cases of SARS-CoV-2 infection, high concentrations of innate inflammatory cytokines, including type I interferons (IFNs), tumor necrosis factor $\alpha$ (TNF- $\alpha$ ), IL-6, IL-1 $\beta$, and some chemokines, including CCL-2, CCL-3, CCL-5, and IP-10, are secreted by epithelial and immune cells [66]. This uncontrolled and excessive release of pro-inflammatory cytokines, i.e., cytokine storm, has been observed in patients infected with influenza virus, SARS-CoV, and MERS-CoV $[66,67]$. A cytokine storm is characterized by a strong proliferation and hyperactivation of $\mathrm{T}$ lymphocytes, overexpression of more than 100 pro-inflammatory genes, and massive endothelial and epithelial cell apoptosis of the lung, which results in alveolar edema, hypoxia and ARDS, and finally, death $[66,68]$. The significant role of this aberrant immune response in severe COVID-19 has inspired the search for antibodies that block pro-inflammatory cytokines such as IL-6 and IL-17 as well as monocyte recruitment elements [68]. Additional immune gene variations have been associated with susceptibility to SARS-related pathogenesis. For instance, the IFN- $\gamma+874 \mathrm{~A}$ allele variant is considered a risk factor for susceptibility to SARS [69]. Interleukin-6 (IL-6, a 21-kDa) glycoprotein polymorphism has been associated with viral infections such as influenza virus, RSV, hepatitis $\mathrm{B}$ virus (HBV), and HCV [70]. For example, the IL6-174 $\mathrm{C} / \mathrm{C}$ genotype (rs1800795) is associated with severe RSV infection [71]. Although IL-6 plays a significant role in the initiation of the cytokine storm in SARS-CoV-2-infected patients, little information is available concerning IL-6 polymorphisms and the pathogenesis of idiopathic pulmonary fibrosis in SARS-CoV-2 infection. A meta-analysis showed that the IL6 $174 \mathrm{C}$ allele is associated with elevated cytokine production and the outcome of pneumonia [72]. Based on the regulatory function of IL-6 for CD4 T cell fate, it can be hypothesized that studying polymorphisms of the IL- 6 genes may provide further insights into COVID-19 pathogenesis [73]. In fact, IL6 polymorphism is considered a valid indicator for the severity or pathology associated with SARS$\mathrm{CoV}-2$ infection. Moreover, Panda et al. reported that the CCR5 $\Delta 32$ polymorphism might influence susceptibility to SARS-CoV-2 infection [74]. Also, IL4 gene polymorphism (SNP: rs2070874; risk allele: T) might influence the outcome of SARS-CoV-1 infection [75].

The IFNAR2 gene is located on chromosome 21q22.11 and encodes the IFN- $\alpha / \beta$ receptor beta chain [76]. Data analysis has shown that polymorphism at the rs2236757 locus of the IFNAR2 gene is associated with the outcome of COVID19 disease [77].

IFNL4 is another gene that might be involved in SARSCoV-2 infection. IFNL4 is located on chromosome 19q13.2 and is involved in the defense against viral infections, such as $\mathrm{HCV}, \mathrm{RSV}$ and influenza virus [78]. Amodio et al. reported that polymorphisms at the rs $368234815 \mathrm{TT} / \Delta \mathrm{G}$ locus of the IFNL4 gene are associated with a higher SARS-CoV-2 viral load [79].

Chemokine (C-C motif) ligand 5 (CCL5), also known as regulated on activation, normal $\mathrm{T}$ cell expressed and secreted (RANTES), is a protein involved in inflammatory and immunoregulatory processes and encoded by the CCL5 gene located on chromosome 17q12 [80-82]. CCL5 gene polymorphism (SNP rs2280788, risk allele, C; SNP rs4239252, risk allele, A), is associated with SARS-CoV-1 infection outcome $[83,86]$.

\section{2'-5'-oligoadenylate synthetase and interferon-induced GTP-binding protein Mx1}

The 2'-5'-oligoadenylate synthetase (OAS) family includes IFN-inducible genes that have a prominent role in innate immunity against viral infections such as picornaviruses. This family include four types of IFN-inducible genes: OAS1, OAS2, OAS3, and OAS-like protein [84]. OAS interferes with viral replication through the induction of apoptosis and inhibition of protein synthesis [84]. 
The OAS-RNase L axis is rapidly activated following cellular infection with various RNA viruses, e.g., flaviviruses, alphaviruses, picornaviruses, and coronaviruses [85, 87]. Moreover, the variant of rs 10735079 in a gene cluster encoding antiviral restriction enzyme activators (OAS1, OAS2, OAS3) is associated with SARS-CoV-2 infection outcome [77]. Human Mx1 is another IFN-type-1-induced gene that is located on chromosome 21q22.3, and the encoded protein targets viral nucleoproteins $[88,89]$. Regarding the role of these genes in innate immunity against viral infections, some studies have suggested that SNPs in the OAS1 gene and MxA promoter might be associated with a higher susceptibility to more-severe SARS infection [90]. In this regard, He et al. reported that SNPs in the 3'-UTR region of the OAS1 gene and the MxA promoter were associated with susceptibility to SARS in the Han population of China [90]. The results of their study revealed that the frequency of the AG and GG genotypes of the OAS1 gene was higher in the control group than in SARS patients. Therefore, they suggested that the $\mathrm{G}$ allele might have a protective effect against SARS-CoV infection [90]. Also, studies have revealed that polymorphisms at the -123 (C/A) and -88 (G7T) loci of the $\mathrm{Mx} 1$ gene affect the levels of protein expression, thereby influencing disease outcomes in patients infected with HBV, $\mathrm{HCV}$, and enterovirus 71, and SARS-CoV [90-98].

\section{CD14}

CD14 is a transmembrane glycoprotein that is located on chromosome $5 \mathrm{q} 31.3$ and expressed on cells of the monocytemacrophage lineage and neutrophils [99]. CD14 is involved in a variety of biological activities, including cell differentiation and host-pathogen interactions, and it is a key molecule in the activation of innate immune cells [99]. It has been reported that the frequency of CD14-159CC polymorphism (rs2569190) is significantly higher among patients suffering from severe SARS, indicating its importance in determining the disease outcome [99]. On the other hand, it has also been reported that IL-10 and TNF- $\alpha$ polymorphisms are not associated with SARS sensitivity [69]. In a study carried out by Tu et al., it was found that the CCL2G-2518A (rs 1024611) polymorphism and variations in codon 54 in MBL (rs1800450) are significantly associated with the risk of SARS-CoV infection [100].

\section{CD209}

The CD209 gene is located on chromosome 19p13.2 and encodes a critical dendritic-cell surface receptor named dendritic cell-specific intercellular adhesion molecule3-grabbing non-integrin (DC-SIGN) [101, 102]. In innate immunity and antiviral defense, DC-SIGN has key functions, including DC migration, antigen uptake, and T-cell priming [103]. DC-SIGN was first discovered as an attachment factor for HIV that binds to the viral envelope glycoprotein and increases the efficiency of infection [104]. Subsequently, DC-SIGN and DC-SIGNR (or L-SIGN) were shown to enhance Ebola virus and SARS-CoV infection [105]. Studies have suggested that polymorphisms in the DC-SIGN gene might be involved in susceptibility/resistance to dengue virus, tick-borne encephalitis virus, cytomegalovirus, and SARS-CoV-2 infection [106, 107, 110]. Supporting this hypothesis, Iyer et al. recently reported that polymorphisms at rs2287886 and rs8105483 are correlated with protection, and those at rs11881682, rs8105572, rs7252229, rs11465384, rs7248637, and rs1146541 are correlated with risk of/susceptibility to symptomatic COVID-19 disease [106] (Table 2). In addition, they revealed that the $G$ allele in rs10518270 and rs2335525 SNPs is a risk allele in SARS-CoV-1 infection [106].

\section{Mucin 5B}

The mucin 5B (MUC5B) gene is located on chromosome 11p15.5 and encodes MUC5B, which plays a role in the viscoelastic and lubricating properties of the mucosa [108]. The MUC5B gene is upregulated in some human diseases related to pulmonary fibrosis and end-stage lung disease [109]. Many symptoms related to MUC5B upregulation in lung disease resemble COVID-19 disease [106]. It has been suggested that the SNPs in the MUC5B gene might be associated with human diseases such as pulmonary fibrosis and COVID-19 disease [106, 110-112]. Iyer et al. reported that polymorphisms at rs2672794, rs56235854, rs7115457, rs2735727, rs12417955, and rs56367042 might be associated with susceptibility to COVID-19 disease and that those at rs2735733, rs2249073, rs2857476 might be associated with comorbidities [106].

\section{IFN-induced transmembrane protein 3}

Another IFN-inducible gene is the IFN-induced transmembrane protein 3 (IFITM3) gene, which is located on chromosome 11p15.5 [113]. This gene encodes a membrane protein that inhibits viral fusion with cholesterol-depleted endosomes [113]. It has been shown that IFITM3 is active against viral infections, including influenza virus, SARS$\mathrm{CoV}$, dengue virus, Ebola virus, and HIV-1 [114, 115]. Functional polymorphisms in this gene have been studied in several infections. Iyer et al. reported that polymorphisms at rs34481144 might have a protective role, whereas those at rs7948108, rs 12252, rs4804800, rs4804803, rs6598045, and rs3888188 might increase susceptibility to SARS-CoV-2 infection [106]. Furthermore, Gómez et al. revealed that the rs12252 C variant of the IFITM3 gene might be associated with COVID-19 disease outcome [116]. 


\section{IFN induced with helicase C domain 1}

The IFN induced with helicase $\mathrm{C}$ domain 1 (IFIH1) gene is located on chromosome $2 \mathrm{q} 24.2$, is induced by IFN type I, and encodes MDA5, an intracellular sensor of viral RNA [117]. It has been reported that the lower frequency of the T allele at the locus rs 1990760 of IFIH1 in the African-American population might be associated with COVID-19 infection outcome due to decreased expression of IFN- $\beta$ [118]. Formyl peptide receptor 1 (FPR1), a pattern-recognition receptor, is involved in the induction of innate immune responses against bacterial infections [119]. Although it has been reported recently that FPR1 expression is involved in lung inflammation and fibrosis, a genetic investigation showed no association between polymorphisms at the rs 867228 and rs 5030880 loci of the FPR1 gene and the severity of COVID-19 disease [120] (Table 2).

\section{Dipeptidyl peptidase 9}

Dipeptidyl peptidase 9 (DPP9) is a Dipeptidyl peptidase 9 (DPP9) is a member of the S9B family, and its gene is located on chromosome 19p13.3 [77]. DPP9 is a serine protease that plays an important role in antigen presentation, activation of inflammasomes, and cleavage of important elements of the immune system such as chemokines (CXCL10, CXCL11, and CXCL12) [121-123]. It has been reported that polymorphisms at the locus rs2109069 of the DPP gene might be associated with COVID-19 outcome. For instance, variations at this location were associated with idiopathic pulmonary fibrosis in COVID-19 patients [77, 124].

\section{Tyrosine kinase 2}

Tyrosine kinase 2 (Tyk2), a member of the Janus kinase (JAK) family, is associated with the cytoplasmic domain of type I and II cytokine receptors [77]. The Tyk2 gene is located on chromosome 19p13.2. It has been reported that polymorphisms at rs2109069 near the Tyk2 gene might be associated with COVID-19 outcome [77].

\section{Human leukocyte antigen}

Human leukocyte antigens (HLAs) are encoded by the major histocompatibility complex (MHC) genes in humans and are responsible for regulation of the immune system. The HLA gene complex is located on chromosome 6p21 [125]. Previous investigations have shown that various polymorphisms of HLA, such as HLA-DR B1*1202, HLA-B*4601,
HLA-B*0703, and HLA-Cw*0801 might predispose carriers to more-severe SARS-CoV infection [126, 127]. In contrast, the HLA-A*0201, HLA-Cw1502, and HLA-DR0301 alleles are correlated with protection from SARS-CoV infection [128], while HLA-DQB $1 * 02: 0$ and HLA-DRB $1 * 11: 01$ are associated with a higher risk of MERS-CoV infection [129]. Amoroso et al. reported that HLA-DRB $1 * 08$ was more frequent in COVID-19 patients and correlated with an increased mortality rate [130].

\section{Other immune system genes}

Alpha-2-HS-glycoprotein (AHSG, alpha-2-HeremansSchmid glycoprotein or fetuin-A) is a protein that is encoded on chromosome $3 q 27.3$ [131]. This protein is synthesized by hepatocytes and adipocytes and has several functions in brain development, endocytosis, and the formation of bone tissue [132]. Like carrier proteins (e.g., albumin) it is present in the serum, and SNPs have been associated with serum fetuin-A levels [133]. Fetuin-A can increase insulin resistance and inflammation, and it is essential for the deactivation of macrophages by modulating endogenous cations [134]. Low serum levels of AHSG have been associated with uncontrolled production of proinflammatory cytokines $[135,136]$. Furthermore, polymorphisms in the AHSG (SNP rs2248690; risk allele, T) gene might affect the outcome of SARS-CoV-1 infection [137]. So far, polymorphisms in this gene have not been studied in COVID-19 patients.

The intercellular adhesion molecule 3 (ICAM3) gene is located on chromosome 19p13.2. ICAM3 acts as an adhesion molecule and a signaling molecule, and it also functions in the initiation of the immune response [138]. ICAM3 gene polymorphisms (SNP rs2304237, risk allele, C; SNP rs3181049, risk allele, A; SNP rs3176767, risk allele, G; SNP rs4611572, risk allele, G; SNP rs2304240, risk allele, G) might affect SARS-CoV-1 infection outcome [139].

The Toll-like receptor 3 (TLR3) gene is located on chromosome 4q35.1. TLR3 is a member of the TLR family of pattern recognition receptors and has an important function in sensing and activation of the innate immune system. An in silico analysis by Teimouri et al. showed that polymorphisms at rs3775290 and rs3775291 enhanced recognition of SARS-CoV-2 dsRNA by TLR3, whereas those at rs73873710 decreased its efficiency [140].

\section{Other gene polymorphisms related to SARS-CoV-2 infection}

\section{Vitamin D binding protein}

Vitamin D binding protein (DBP) is a multifunctional protein that is involved in various clinical conditions by 
regulating vitamin D metabolite levels [141]. The DBP gene is located on chromosome 4q11-q13 and is predominantly expressed in liver tissue [142]. Some factors such as estrogen, glucocorticoid, and inflammatory cytokines modulate DBP expression levels. Consisting of 458 amino acids, DBP has been identified as the most polymorphic protein [142]. Allele variations have a substantial impact on its biological functions (e.g., the alleles Gc1s (rs7041 locus) and Gc2 (rs4588 locus) increase the affinity of DBP for vitamin $D$ and are associated with lower free vitamin $D$ levels [141]. In HCV infection, the G allele at the rs7041 locus has been reported to be associated with the expression of a high-affinity receptor, which increases the risk of infection [143]. People carrying the GG genotype at the rs4588 locus of the Gc2 polymorphic region have lower levels of $25(\mathrm{OH}) \mathrm{D}$ compared to individuals carrying the AA genotype following vitamin D supplementation [144]. Batur et al. showed that DBP variations such as the GT genotype at rs7041 are significantly correlated with a higher frequency of COVID-19-related deaths, while the TT genotype showed a significant negative correlation with mortality [141]. In addition, the polymorphism at the rs4588 locus had no significant impact on COVID-19 severity [141]. These findings indicate that variations in mortality rate may be explained by DBP polymorphisms, which affect vitamin D metabolism [141].

\section{Vitamin D receptor}

The vitamin D receptor (VDR) gene is located in the region q13.11 of chromosome 12 [145]. VDR is a nuclear receptor that functions as a transcription factor when activated by its ligand [146]. Most of the VDR activity is controlled by the interaction with the ligand 1,25(OH)2D, but some functions are vitamin-D-independent. [147, 148]. VDR belongs to the steroid receptor family, which includes retinoic acid, thyroid hormone, sex hormones, and adrenal steroid receptors, which have a broad distribution among different cells $[149,150]$. Vitamin D signaling is involved in calcium and bone homeostasis, skin biology, immune health, oral health, cancers, and cardiovascular diseases [148]. Many cells of the innate and adaptive immune system express VDR. Some of these cells express CYP27B1 for producing the biologically active form of vitamin D [148]. Data from experiments using animal models have demonstrated that vitamin D/VDR signaling modulates autoimmune $\mathrm{T}$ cell responses and immuneinflammatory reactions, but the physiological activity in humans is not completely understood [151]. Therefore, its role in the pathogenesis and outcome of immune-inflammatory diseases remains to be elucidated [148, 152].

Based on a meta-analysis by Laplana et al., a polymorphism at locus rs 2228570 was associated with viral infections. The TT genotype and $\mathrm{T}$ allele were reported to be risk factors for infections with enveloped viruses, including RSV [153]. There are numerous findings indicating that vitamin D supplementation can reduce the risk of severe infection and death related to influenza and COVID-19. However, none of the studies have reported the importance of vitamin D receptor polymorphisms in COVID-19 disease outcome [154]. When examining the antimicrobial role of vitamin D in different populations, we need to take VDR polymorphisms into account.

\section{Glucose-regulated protein 78 kDa}

Glucose-regulated protein (GRP78), or heat shock protein family A (HSPA) member 5, belongs to the HSP70 family and is found on the membrane of the endoplasmic reticulum (ER). The gene encoding this protein is located on chromosome 9q33.3 [155, 156]. GRP78 plays an accessory role in many stages of the viral life cycle, including viral attachment and entry (facilitating or alternative factor), protein production (proper folding and processing), release (assembly and maturation), and re-infectivity (released together with mature virions and acting as accessory infectivity factor) [157]. Bioinformatic modeling has predicted favorable binding between GRP78 and the III (C391-C525) and IV (C480-C488) regions of the SARS-CoV-2 S protein [158]. In cells harboring the $-415 \mathrm{~A} /-180 \mathrm{G}$ allele, expression of HSPA5 was significantly increased compared to cells harboring the $-415 \mathrm{G} /-180$ del allele following ER stress [159]. GRP78 expression and its polymorphisms may be associated with SARS-CoV-2 infection and mortality rates, but their role in COVID-19 is still poorly understood.

\section{CD147 polymorphisms}

CD147 is a cell-surface glycoprotein belonging to the immunoglobulin superfamily that plays a role in intercellular recognition [160]. The CD147 gene encompasses a stretch of $7500 \mathrm{bp}$ on chromosome 19p13.3 and encodes a protein from eight exons [161, 162]. CD147 is also known as extracellular matrix metalloproteinase inducer (EMMPRIN) or basigin and is expressed by a variety of cell types, including endothelial cells, epithelial cells, and lymphocytes [163-166]. It has been reported that CD147 regulates proliferation, differentiation, migration, metastasis, and apoptosis of tumor cells, particularly in hypoxic situations $[167,168]$. Therefore, the role of CD147 in the progression and metastasis of tumors has been studied [169].

CD147 has recently been identified as a marker of inflammation [170]. Moreover, some studies have shown that CD147 is an important molecule in proteolysis and inflammation [171]. CD147 has various ligands, e.g., integrins, cyclophilin, and Plasmodium falciparum reticulocyte 
binding-like homologue 5 [168]. The role of CD147 in infections by viruses such as Kaposi's sarcoma-associated herpesvirus (KSHV), HBV, HCV, and HIV has been studied extensively, and these studies have supported the importance of CD147 in viral pathogenesis and tumorigenesis [168]. Interactions of CD147 with cyclophilin A during HIV infection accelerate its uptake into cells. A similar mechanism has been reported for SARS coronavirus infection [172, 173]. Furthermore, CD147 on epithelial cells acts as a receptor for measles virus [174]. Studies have reported that the CD147 gene contains a number of SNPs in coding and regulatory regions, including rs2283574, rs6757, rs8637, rs4919862, rs6758, rs8259, rs4919859, and rs28915400. These regions might be involved in numerous diseases and disorders [175, 176]. For instance, it has been reported that polymorphisms in the CD147 gene might effectively contribute to the initiation and progression of acute coronary syndrome and skin diseases [171, 177, 178]. Although CD147 has been studied in the context of viral pathogenesis and tumorigenesis, the significance of its polymorphisms in viral infection outcome remains to be determined [168].

Recent studies have suggested that CD147 can serve as an alternative receptor for SARS-CoV-2 [179]. Although some studies have investigated ACE-2 polymorphisms that enhance or diminish binding of the $S$ protein to ACE-2, polymorphisms that affect $S$ protein binding to CD147 have not been reported in SARS-CoV-2 infection. Meanwhile, $\mathrm{Wu}$ et al. have reported that the polymorphism T/A (rs8259) in the 3'-UTR of the CD147 gene, which interacts with miR492, alters the expression of CD147 [178]. However, no studies have been conducted to investigate the relationship between SNPs of CD147 or miRNA-492 and the risk of SARS-CoV-2 infection. miRNA-492 is encoded on chromosome $12 \mathrm{q} 22$ and binds to complementary sequences in the 3'-UTRs of target mRNAs.

\section{Dipeptidyl peptidase 4 (DPP4)}

Dipeptidyl peptidase 4 (DPP4), also known as CD26, is encoded by the DPP4 gene, which is located on chromosome $2 \mathrm{q} 24.2$ [180]. DPP4 is a serine exopeptidase that is expressed on the surface of most cell types and cleaves $\mathrm{X}$-alanine or X-proline dipeptides from the $\mathrm{N}$-termini of polypeptides. DPP4 has been identified as the cellular entry receptor for MERS-CoV. Current data suggest that CD26 does not act as a receptor for SARS-COV-2 [181]. However, one study has shown that polymorphisms in the rs 13015258 locus in the CD26 gene affect the expression of key regulatory genes related to internalization of SARS-CoV-2 into the host cell [62].

\section{Neuropilin 1}

Understanding the mechanisms and pathways involved in the cellular entry of SARS-CoV-2 is essential to delineate virus tropism to develop preventive strategies. In addition to ACE-2 and CD147, receptor for advanced glycation endproducts (RAGE), and olfactory receptors, recent experiments have suggested neuropilin 1 (NRP-1) to be a new mediator of SARS-CoV-2 entry in the nervous system [181, 182]. An in vitro study confirmed the direct binding of the S1 CendR motif of SARS-CoV-2 NRP-1 [181]. Moreover, it has been shown that NRP-1 binds to furin-cleaved substrates and consequently enhances the infectivity of SARS-CoV-2. This mechanism can be targeted by NRP-1 monoclonal antibodies to block entry of the cell by the virus [182].

NRP-1 is a type I transmembrane protein, and its gene is located on chromosome 10p11.22 [153]. NRP-1 is involved in providing cues for axonal guidance and neuronal development. Furthermore, it has been identified as a co-receptor for multiple ligands, such as vascular endothelial growth factor (VEGF), semaphorins (SEMA), and transforming growth factor beta (TGF- $\beta$ ) $[184,185]$. A higher level of expression of NRP-1 has been detected in the upper respiratory tract and olfactory epithelium covering the nasal cavity [186]. Similar polybasic furin-type cleavage sites (RRAR ${ }^{\wedge}$ ) in the $S 1-S 2$ junction of the spike glycoproteins have been observed in other human viruses including Ebola virus, HIV-1, and highly virulent strains of avian influenza virus. In contrast, a similar site was found to be lacking in SARS-CoV-1 [187, 188].

There are a growing number of studies investigating the role of NRP-1 in the immune response. Hwang et al. demonstrated that NRP-1 regulates the secondary CD8 T cell response to viral infections. NRP-1 was also found to be important for the function of regulatory T (Treg) cells [189]. Overexpression of NRP-1 in T-reg cells enhances their interactions with dendritic cells, which attenuated the immune responses in the absence of danger signals. Based on these findings, polymorphisms in the NRP-1 gene might affect the immune response to SARS-CoV-2 infection by inhibiting antigen presentation in the lymph nodes and subsequent viral clearance. In one study, 11 functional SNPs were reported in the NRP-1 gene, which have been associated with various clinical conditions. For instance, a polymorphism at rs2228638 was shown to be associated with an increased risk of cyanotic congenital heart disease [190]. Recently, it was reported that binding of miR-338 to the 3'-UTR of NRP-1 significantly inhibits the expression of NRP-1. Since the rs 10080 SNP is located in the 3'-UTR region, it might affect the expression pattern of NRP-1 [190]. For instance, it has been reported that the $\mathrm{G}$ allele of rs 10080 can downregulate the expression of NRP-1 [191]. Therefore, individuals carrying the $\mathrm{G}$ allele might express lower levels of NRP-1 on 
the target cells, which alters the neuropathogenesis associated with COVID-19 disease. More investigations regarding the effect of SNPs in NRP-1 on the pathogenesis of SARS$\mathrm{CoV}-2$ infection in other tissues are recommended.

\section{Heme oxygenase 1}

Heme oxygenase 1 (HO-1, HMOX1) is located on chromosome 22q12.3 [191]. The heme oxygenase system is an antiinflammatory cytoprotecting system that includes HO-1 and HO-2. It degrades heme to bilirubin, free iron, and carbon monoxide and plays an important role in the antioxidant and antiapoptotic activity of the cells [192]. The high-affinity binding of the SARS-CoV-2 spike protein to porphyrin [193] upregulates the formation of reactive oxygen species (ROS) and free heme and decreases the level of HO-1 [192, 194, 195]. Therefore, the SARS-CoV-2-porphyrin complex may cause impairment of HO-1 signaling by downregulating HO-1 gene expression, which results in severe oxidative stress induced by free heme and iron [192, 194, 196]. It has been reported that a genetic polymorphism, a di-nucleotide repeat of GT, in the promoter region of the HO-1 affects the transcription of HO-1 and might be associated with the COVID-19-induced cytokine storm [192, 197-202]. In this regard, Fakhouri et al. concluded that individuals with longer GT repeats in the HO-1 promoter were at higher risk of developing severe COVID-19 disease [192]. Moreover, it has been reported that the $\mathrm{T}$ allele at the locus rs2071746 of the HO- 1 gene can modulate the expression of HO-1 and influence the severity of COVID-19 disease [203].

\section{Apolipoprotein L1}

Apolipoprotein L1 (APOL1), a member of APOL gene family, is encoded by a gene located on chromosome 22q12.3 [204]. APOLs play important roles in lipid transport and metabolism, innate immunity, apoptosis, and autophagy [205-211]. Furthermore, APOL1 is involved in inflammatory and pro-inflammatory responses. For instance, cytokines such as TNF- $\alpha$ and IFN- $\gamma$ can upregulate APOL1 expression [210]. Recently, the relationship between COVID-19 disease and APOL1 polymorphism in African patients was reported [212]. These researchers emphasized the potential key role of G1 and G2 alleles in the formation of collapsed focal segmental glomerulosclerosis (FSGS) related to SARS-CoV-2 [212]. Moreover, Larsen et al. reported that CG variants of the APOL1 gene were associated with COVID-19-related severity of kidney disease [213]. The CG genotype has not been reported in Chinese and European populations. Therefore, the high-risk APOL1 genotypes might exist only in African populations [213, 214].
Vitamin K epoxide reductase complex subunit 1

The vitamin $\mathrm{K}$ epoxide reductase complex 1 (VKORC1) gene is located on chromosome 16p11.2 [215]. Polymorphism at the regulatory -1639A locus of the VKORC1 gene is common in the East Asian population and is associated with low vitamin $\mathrm{K}$ turnover [216]. Based on reported data, it has been proposed that VKORC1-1639A polymorphisms (rs9923231) are associated with protection against thrombotic complications of COVID-19 infection, which might partially explain the differences in the severity of COVID19 infection between Western and Eastern countries [217].

\section{ABO blood group system}

The ABO blood group system is based on the presence or absence of A and B glycan antigens on red blood cells. A particular $\mathrm{ABO}$ blood type might confer resistance to infectious diseases. Several studies found an association between the $\mathrm{ABO}$ blood group and susceptibility to SARS-CoV-2 infection. For instance, individuals with blood group $\mathrm{O}$ had a lower risk of infection than those with blood group A [130, 218]. Moreover, SNP rs657152 at the locus 9q34.2, which mapped on the ABO locus, was reported to be a genetic susceptibility locus in COVID-19 patients diagnosed with respiratory failure [219].

\section{Conclusion}

In addition to being a local respiratory disease, COVID-19 is a complex multi-organ disease in which human genetic polymorphisms play a distinctive role in the disease outcome. Currently, there is insufficient and controversial knowledge about the role of gene polymorphisms in the pathogenesis of SARS-CoV-2 infection. In this review, we have provided a comprehensive overview of the relevant research data currently available. The affinity-determining variants in the ACE-2 gene, such as rs2285666, rs4646116, rs267606406, rs143936283, rs961360700, rs146676783, and rs 1244687367, are associated with SARS-CoV-2 infection outcome. The expression level of TMPRSS 2 plays a considerable role in determining the severity of COVID-19. Polymorphisms in the TMPRSS2 gene, including rs2070788, rs9974589, and rs7364083, are associated with increased expression of this gene. The $\mathrm{G}$ allele at rs 10080 of the NRP-1 gene might be associated with lower expression of the NRP-1 protein on target cells and might result in decreased COVID-19 pathogenesis. Moreover, polymorphisms in the immune-related genes, including TLR3, IFNL4, IFIH1, and CCR5, are likely to influence the outcome of COVID-19 disease. Finally, genetic polymorphisms in some other genes, 
including the HO-1, APOL1, VKORC1, DPP4, and DBP genes, might influence the SARS-CoV-2 infection outcome. The present review was an attempt to clarify the importance of human gene polymorphisms in the clinical outcome of SARS-CoV-2 infection. This overview provides insights for disease management and control.

Author contributions All authors contributed to the writing and revision of the manuscript. All authors read and approved the final manuscript.

Funding The present study was financially supported by Shiraz University of Medical Sciences (Grant no. 22169)

\section{Declarations}

Conflict of interest The authors declare no conflict of interest.

\section{References}

1. Coronaviridae Study Group of the International Committee on Taxonomy of Viruses (2020) The species Severe acute respiratory syndrome-related coronavirus: classifying 2019-nCoV and naming it SARS-CoV-2. Nat Microbiol 5(4):536-544. https:// doi.org/10.1038/s41564-020-0695-z

2. Harapan H, Itoh N, Yufika A, Winardi W, Keam S, Te H, Megawati D, Hayati Z, Wagner AL, Mudatsir M (2020) Coronavirus disease 2019 (COVID-19): a literature review. J Infect Public Health 13(5):667-673. https://doi.org/10.1016/j.jiph.2020.03. 019

3. Woo PC, Huang Y, Lau SK, Yuen K-Y (2010) Coronavirus genomics and bioinformatics analysis. Viruses 2(8):1804-1820. https://doi.org/10.3390/v2081803

4. Khailany RA, Safdar M, Ozaslan M (2020) Genomic characterization of a novel SARS-CoV-2. Gene Rep 19:100682. https://doi. org/10.1016/j.genrep.2020.100682

5. Pourkarim MR, Thijssen M, Lemey P, Vandamme A-M, Van Ranst M (2020) Air conditioning system usage and SARS-CoV-2 transmission dynamics in Iran. Med Hypotheses 143:110164. https://doi.org/10.1016/j.mehy.2020.110164

6. Wu P, Hao X, Lau EH, Wong JY, Leung KS, Wu JT, Cowling BJ, Leung GM (2020) Real-time tentative assessment of the epidemiological characteristics of novel coronavirus infections in Wuhan, China, as at 22 January 2020. Euro Surveill 25(3):2000044. https://doi.org/10.2807/1560-7917.ES.2020.25.3.2000044

7. Zhu N, Zhang D, Wang W, Li X, Yang B, Song J, Zhao X, Huang B, Shi W (2020) Lu R (2020) A novel coronavirus from patients with pneumonia in China, 2019. N Engl J Med 382:727-733. https://doi.org/10.1056/NEJMoa2001017

8. Olson DR, Simonsen L, Edelson PJ, Morse SS (2005) Epidemiological evidence of an early wave of the 1918 influenza pandemic in New York City. Proc Natl Acad Sci USA 102(31):1105911063. https://doi.org/10.1073/pnas.0408290102

9. Chowell G, Bertozzi SM, Colchero MA, Lopez-Gatell H, Alpuche-Aranda C, Hernandez M (2009) Miller MA (2009) Severe respiratory disease concurrent with the circulation of H1N1 influenza. N Engl J Med 361:674-679. https://doi.org/10. 1056/NEJMoa0904023
10. Huang S-H, Su M-C, Tien N, Huang C-J, Lan Y-C, Lin C-S, Chen C-H, Lin C-W (2017) Epidemiology of human coronavirus NL63 infection among hospitalized patients with pneumonia in Taiwan. J Microbiol Immunol Infect 50(6):763-770. https://doi. org/10.1016/j.jmii.2015.10.008

11. Lee KH, Yoo SG, Cho Y, La Y, Han SH, Kim MS, Choi JS, Kim SI, Kim YS, Min YH (2019) Characteristics of communityacquired respiratory viruses infections except seasonal influenza in transplant recipients and non-transplant critically ill patients. J Microbiol Immunol Infect. https://doi.org/10.1016/j.jmii.2019. 05.007

12. Miller DS, Kok T, Li P (2013) The virus inoculum volume influences outcome of influenza A infection in mice. Lab Anim 47(1):74-77. https://doi.org/10.1258/la.2012.011157

13. Zheng Z, Peng F, Xu B, Zhao J, Liu H, Peng J, Li Q, Jiang C, Zhou Y, Liu S (2020) Risk factors of critical \& mortal COVID19 cases: a systematic literature review and meta-analysis. J Infect 81(2):e16-e25. https://doi.org/10.1016/j.jinf.2020.04.021

14. Li X, Xu S, Yu M, Wang K, Tao Y, Zhou Y, Shi J, Zhou M, Wu B, Yang Z (2020) Risk factors for severity and mortality in adult COVID-19 inpatients in Wuhan. J Allergy Clin Immunol 146(1):110-118. https://doi.org/10.1016/j.jaci.2020.04.006

15. Asselta R, Paraboschi EM, Mantovani A, Duga S (2020) ACE2 and TMPRSS2 variants and expression as candidates to sex and country differences in COVID-19 severity in Italy. Aging (Albany NY) 12(11):10087-10098. https://doi.org/10.18632/ aging. 103415

16. Mousavizadeh L, Ghasemi S (2020) Genotype and phenotype of COVID-19: their roles in pathogenesis. J Microbiol Immunol Infect. https://doi.org/10.1016/j.jmii.2020.03.022

17. Chen N, Zhou M, Dong X, Qu J, Gong F, Han Y, Qiu Y, Wang J, Liu Y, Wei Y (2020) Epidemiological and clinical characteristics of 99 cases of 2019 novel coronavirus pneumonia in Wuhan, China: a descriptive study. Lancet 395(10223):507513. https://doi.org/10.1016/S0140-6736(20)30211-7

18. Teymoori-Rad M, Samadizadeh S, Tabarraei A, Moradi A, Shahbaz MB, Tahamtan A (2020) Ten challenging questions about SARS-CoV-2 and COVID-19. Expert Rev Respir Med 14(9):881-888. https://doi.org/10.1080/17476348.2020.17821 97

19. Zhang Q, Bastard P, Liu Z, Le Pen J, Moncada-Velez M, Chen J, Ogishi M, Sabli IK, Hodeib S, Korol C (2020) Inborn errors of type I IFN immunity in patients with life-threatening COVID-19. Science 370(6515):eabd4570. https://doi.org/10.1126/science. abd 4570

20. Riordan JF (2003) Angiotensin-I-converting enzyme and its relatives. Genome Biol 4(8):225. https://doi.org/10.1186/ gb-2003-4-8-225

21. Itoyama S, Keicho N, Quy T, Phi NC, Long HT, Van Ban V, Ohashi J, Hijikata M, Matsushita I, Kawana A (2004) ACE1 polymorphism and progression of SARS. Biochem Biophys Res Commun 323(3):1124-1129. https://doi.org/10.1016/j.bbrc. 2004.08.208

22. Rigat B, Hubert C, Alhenc-Gelas F, Cambien F, Corvol P, Soubrier F (1990) An insertion/deletion polymorphism in the angiotensin I-converting enzyme gene accounting for half the variance of serum enzyme levels. J Clin Invest 86(4):1343-1346. https:// doi.org/10.1172/JCI114844

23. Imai Y, Kuba K, Ohto-Nakanishi T, Penninger JM (2010) Angiotensin-converting enzyme 2 (ACE2) in disease pathogenesis. Circ J 74(3):405-410. https://doi.org/10.1253/circj.cj-10-0045

24. Kehoe PG, Russ C, McIlroy S, Williams H, Holmans P, Holmes C, Liolitsa D, Vahidassr D, Powell J, McGleenon B (1999) Variation in DCP1, encoding ACE, is associated with susceptibility to Alzheimer disease. Nat Genet 21(1):71-72. https://doi.org/10. $1038 / 5009$ 
25. Kölsch H, Jessen F, Freymann N, Kreis M, Hentschel F, Maier W, Heun R (2005) ACE I/D polymorphism is a risk factor of Alzheimer's disease but not of vascular dementia. Neurosci Lett. 377(1):37-39. https://doi.org/10.1016/j.neulet.2004.11.062

26. Elkins JS, Douglas VC, Johnston SC (2004) Alzheimer disease risk and genetic variation in ACE: a meta-analysis. Neurology 62(3):363-368. https://doi.org/10.1212/01.wnl.0000106823. 72493.ff

27. Butler R (2000) The DD-ACE genotype and cardiovascular disease. Pharmacogenomics 1(2):153-167. https://doi.org/10.1517/ 14622416.1.2.153

28. Mackawy AM, Badawy ME, Megahed O (2012) Angiotensin converting enzyme (ACE D/I) polymorphism and its relation to liver fibrosis progression in Egyptian patients with chronic hepatitis C virus infection. Egypt J Med Hum Genet 13(3):291-299. https://doi.org/10.1016/j.ejmhg.2012.06.006

29. Xiao Y, Dong Z, Zhu J, You J, Fan J (2019) Association between ACE A240T polymorphism and cancer risk: a meta-analysis. J Int Med Res 47(12):5917-5925. https://doi.org/10.1177/03000 60519882559

30. Marshall RP, Webb S, Bellingan GJ, Montgomery HE, Chaudhari B, McAnulty RJ, Humphries SE, Hill MR, Laurent GJ (2002) Angiotensin converting enzyme insertion/deletion polymorphism is associated with susceptibility and outcome in acute respiratory distress syndrome. Am J Respir Crit Care Med 166(5):646-650. https://doi.org/10.1164/rccm.2108086

31. Yamamoto N, Ariumi Y, Nishida N, Yamamoto R, Bauer G, Gojobori T, Shimotohno K, Mizokami M (2020) SARS-CoV-2 infections and COVID-19 mortalities strongly correlate with ACE1 I/D genotype. Gene 758:144944. https://doi.org/10.1016/j. gene.2020.144944

32. Chan KA, Tang NL, Hui DS, Chung GT, Wu AK, Chim SS, Chiu RW, Lee N, Choi K, Sung YM (2005) Absence of association between angiotensin converting enzyme polymorphism and development of adult respiratory distress syndrome in patients with severe acute respiratory syndrome: a case control study. BMC Infect Dis 5(1):26. https://doi.org/10.1186/1471-2334-5-26

33. Koh W-P, Yuan J-M, Sun C-L, van den Berg D, Seow A, Lee H-P, Mimi CY (2003) Angiotensin I-converting enzyme (ACE) gene polymorphism and breast cancer risk among Chinese women in Singapore. Clin Cancer Res 63(3):573-578

34. Tipnis SR, Hooper NM, Hyde R, Karran E, Christie G, Turner AJ (2000) A human homolog of angiotensin-converting enzyme cloning and functional expression as a captopril-insensitive carboxypeptidase. J Biol Chem 275(43):33238-33243. https://doi. org/10.1074/jbc.M002615200

35. Hoffmann M, Kleine-Weber H, Schroeder S, Krüger N, Herrler T, Erichsen S, Schiergens T, Herrler G, Wu N, Nitsche A, Müller MA, Drosten C, Pöhlmann S (2020) SARS-CoV-2 cell entry depends on ACE2 and TMPRSS2 and is blocked by a clinically proven protease inhibitor. Cell 181(2):271.e8-280.e8. https://doi. org/10.1016/j.cell.2020.02.052

36. Medina-Enríquez MM, Lopez-León S, Carlos-Escalante JA, Aponte-Torres Z, Cuapio A, Wegman-Ostrosky T (2020) ACE2: the molecular doorway to SARS-CoV-2. Cell Biosci. 10(1):148. https://doi.org/10.1186/s13578-020-00519-8

37. Hamming I, Timens W, Bulthuis M, Lely A, Navis G, van Goor H (2004) Tissue distribution of ACE2 protein, the functional receptor for SARS coronavirus. A first step in understanding SARS pathogenesis. J Pathol 203(2):631-637. https://doi.org/10.1002/ path. 1570

38. Tikellis C, Thomas M (2012) Angiotensin-converting enzyme 2 (ACE2) is a key modulator of the renin angiotensin system in health and disease. Int J Pept. https://doi.org/10.1155/2012/ 256294
39. Jacoby DS, Rader DJ (2003) Renin-angiotensin system and atherothrombotic disease: from genes to treatment. Arch Intern Med 163(10):1155-1164. https://doi.org/10.1001/archinte.163. 10.1155

40. Benter IF, Yousif MH, Al-Saleh FM, Chappell RRMC, Diz DI (2011) Angiotensin-(1-7) blockade attenuates captopril-or hydralazine-induced cardiovascular protection in spontaneously hypertensive rats-treated with L-NAME. J Cardiovasc Pharmacol. 57(5):559-567. https://doi.org/10.1097/FJC.0b013e3182 $1324 \mathrm{~b} 6$

41. Pieruzzi F, Abassi ZA, Keiser HR (1995) Expression of reninangiotensin system components in the heart, kidneys, and lungs of rats with experimental heart failure. Circulation 92(10):31053112. https://doi.org/10.1161/01.cir.92.10.3105

42. Donoghue M, Hsieh F, Baronas E, Godbout K, Gosselin M, Stagliano N, Donovan M, Woolf B, Robison K, Jeyaseelan R (2000) A novel angiotensin-converting enzyme-related carboxypeptidase (ACE2) converts angiotensin I to angiotensin 1-9. Circ Res 87(5):E1-9. https://doi.org/10.1161/01.res.87.5.e1

43. Kiely DG, Cargill RI, Wheeldon NM, Coutie WJ, Lipworth BJ (1997) Haemodynamic and endocrine effects of type 1 angiotensin II receptor blockade in patients with hypoxaemic cor pulmonale. Cardiovasc Res 33(1):201-208. https://doi.org/10.1016/ s0008-6363(96)00180-0

44. LiF L, Farzan M (2005) Structure of SARS coronavirus spike receptor $\mathrm{G}$ binding domain complexed with receptor. Science 309(5742):1864-1868. https://doi.org/10.1126/science.1116480

45. Srivastava A, Bandopadhyay A, Das D, Pandey RK, Singh V, Khanam N, Srivastava N, Singh PP, Dubey PK, Pathak A (2020) Genetic association of ACE2 rs2285666 polymorphism with Covid-19 spatial distribution in India. Front Genet 11:564741. https://doi.org/10.3389/fgene.2020.564741

46. Wang J, Xu X, Zhou X, Chen P, Liang H, Li X, Zhong W, Hao P (2020) Molecular simulation of SARS-CoV-2 spike protein binding to pangolin ACE2 or human ACE2 natural variants reveals altered susceptibility to infection. J Gen Virol 101(9):921-924. https://doi.org/10.1099/jgv.0.001452

47. Mohammad A, Marafie SK, Alshawaf E, Abu-Farha M, Abubaker J, Al-Mulla F (2020) Structural analysis of ACE2 variant N720D demonstrates a higher binding affinity to TMPRSS2. Life Sci 259:118219. https://doi.org/10.1016/j.lfs.2020.118219

48. Calcagnile M, Forgez P, Iannelli A, Bucci C, Alifano M, Alifano $P$ (2021) Molecular docking simulation reveals ACE2 polymorphisms that may increase the affinity of ACE2 with the SARSCoV-2 Spike protein. Biochimie 180:143-148. https://doi.org/ 10.1016/j.biochi.2020.11.004

49. Hashizume M, Gonzalez G, Ono C, Takashima A, Iwasaki M (2021) Population-specific ACE2 single-nucleotide polymorphisms have limited impact on SARS-CoV-2 infectivity in vitro. Viruses 13(1):67. https://doi.org/10.3390/v13010067

50. Glowacka I, Bertram S, Herzog P, Pfefferle S, Steffen I, Muench MO, Simmons G, Hofmann H, Kuri T, Weber F (2010) Differential downregulation of ACE2 by the spike proteins of severe acute respiratory syndrome coronavirus and human coronavirus NL63. J Virol 84(2):1198-1205. https://doi.org/10.1128/JVI.01248-09

51. Sodhi CP, Wohlford-Lenane C, Yamaguchi Y, Prindle T, Fulton WB, Wang S, McCray PB Jr, Chappell M, Hackam DJ, Jia H (2018) Attenuation of pulmonary ACE2 activity impairs inactivation of des-Arg9 bradykinin/BKB1R axis and facilitates LPS-induced neutrophil infiltration. Am J Physiol Lung Cell Mol Physiol 314(1):L17-L31. https://doi.org/10.1152/ajplung. 00498.2016

52. Cristiani L, Mancino E, Matera L, Nenna R, Pierangeli A, Scagnolari C, Midulla F (2020) Will children reveal their secret? The coronavirus dilemma. Eur Respir Soc 55:2001382. https://doi. org/10.1183/13993003.00749-2020 
53. Kuba K, Imai Y, Rao S, Gao H, Guo F, Guan B, Huan Y, Yang P, Zhang Y, Deng W (2005) A crucial role of angiotensin converting enzyme 2 (ACE2) in SARS coronavirus-induced lung injury. Nat Med 11(8):875-879. https://doi.org/10.1038/nm1267

54. Imai Y, Kuba K, Rao S, Huan Y, Guo F, Guan B, Yang P, Sarao R, Wada T, Leong-Poi H (2005) Angiotensin-converting enzyme 2 protects from severe acute lung failure. Nature 436(7047):112116. https://doi.org/10.1038/nature03712

55. Gu H, Xie Z, Li T, Zhang S, Lai C, Zhu P, Wang K, Han L, Duan Y, Zhao Z (2016) Angiotensin-converting enzyme 2 inhibits lung injury induced by respiratory syncytial virus. Sci Rep 6:19840. https://doi.org/10.1038/srep19840

56. Huang F, Guo J, Zou Z, Liu J, Cao B, Zhang S, Li H, Wang W, Sheng M, Liu S (2014) Angiotensin II plasma levels are linked to disease severity and predict fatal outcomes in H7N9-infected patients. Nat Commun 5:3595. https://doi.org/10.1038/ncomm s4595

57. Yan Y, Liu Q, Li N, Du J, Li X, Li C, Jin N, Jiang C (2015) Angiotensin II receptor blocker as a novel therapy in acute lung injury induced by avian influenza A H5N1 virus infection in mouse. Science China. Life sciences 58(2):208-211. https:// doi.org/10.1007/s11427-015-4814-7

58. Mertz KD, Setlur SR, Dhanasekaran SM, Demichelis F, Perner S, Tomlins S, Tchinda J, Laxman B, Vessella RL, Beroukhimt R (2007) Molecular characterization of TMPRSS2-ERG gene fusion in the NCI-H660 prostate cancer cell line: a new perspective for an old model. Neoplasia 9(3):200-IN203. https:// doi.org/10.1593/neo.07103

59. Lucas JM, Heinlein C, Kim T, Hernandez SA, Malik MS, True LD, Morrissey C, Corey E, Montgomery B, Mostaghel E (2014) The androgen-regulated protease TMPRSS2 activates a proteolytic cascade involving components of the tumor microenvironment and promotes prostate cancer metastasis. Cancer Discov 4(11):1310-1325. https://doi.org/10.1158/2159-8290. CD-13-1010

60. Maekawa S, Suzuki M, Arai T, Suzuki M, Kato M, Morikawa T, Kasuya Y, Kume H, Kitamura T, Homma Y (2014) TMPRSS2 $\mathrm{M}$ et160 V al polymorphism: significant association with sporadic prostate cancer, but not with latent prostate cancer in J apanese men. Int J Urol 21(12):1234-1238. https:// doi.org/10.1111/iju.12578

61. Baena E, Shao Z, Linn DE, Glass K, Hamblen MJ, Fujiwara Y, Kim J, Nguyen M, Zhang X, Godinho FJ (2013) ETV1 directs androgen metabolism and confers aggressive prostate cancer in targeted mice and patients. Genes Dev 27(6):683-698. https:// doi.org/10.1101/gad.211011.112

62. Senapati S, Kumar S, Singh AK, Banerjee P, Bhagavatula S (2020) Assessment of risk conferred by coding and regulatory variations of TMPRSS2 and CD26 in susceptibility to SARSCoV-2 infection in human. J Genet Genom. https://doi.org/10. 1007/s12041-020-01217-7

63. Irham LM, Chou W-H, Calkins MJ, Adikusuma W, Hsieh S-L, Chang W-C (2020) Genetic variants that influence SARS-CoV-2 receptor TMPRSS2 expression among population cohorts from multiple continents. Biochem Biophys Res Commun 529(2):263-269. https://doi.org/10.1016/j.bbrc.2020. 05.179

64. Torre-Fuentes L, Matías-Guiu J, Hernández-Lorenzo L, Montero-Escribano P, Pytel V, Porta-Etessam J, Gómez-Pinedo U, Matías-Guiu JA (2021) ACE2, TMPRSS2, and Furin variants and SARS-CoV-2 infection in Madrid, Spain. J Med Virol 93(2):863-869. https://doi.org/10.1002/jmv.26319

65. Cheng Z, Zhou J, To KK-W, Chu H, Li C, Wang D, Yang D, Zheng S, Hao K, Bossé Y (2015) Identification of TMPRSS2 as a susceptibility gene for severe 2009 pandemic A (H1N1) influenza and A (H7N9) influenza. J Infect Dis 212(8):12141221. https://doi.org/10.1093/infdis/jiv246

66. Coperchini F, Chiovato L, Croce L, Magri F, Rotondi M (2020) The Cytokine storm in COVID-19: An overview of the involvement of the chemokine/chemokine-receptor system. Cytokine Growth Factor Rev 53:25-32. https://doi.org/10.1016/j.cytog fr.2020.05.003

67. Zhao Z, Wei Y, Tao C (2021) An enlightening role for cytokine storm in coronavirus infection. Clin Immunol 222:108615. https://doi.org/10.1016/j.clim.2020.108615

68. Sun X, Wang T, Cai D, Hu Z, Liao H, Zhi L, Wei H, Zhang Z, Qiu Y, Wang J (2020) Cytokine storm intervention in the early stages of COVID-19 pneumonia. Cytokine Growth Factor Rev 53:38-42. https://doi.org/10.1016/j.cytogfr.2020.04.002

69. Chong WP, Ip WE, Tso GHW, Ng MW, Wong WHS, Law HKW, Yung RW, Chow EY, Au K, Chan EY (2006) The interferon gamma gene polymorphism $+874 \mathrm{~A} / \mathrm{T}$ is associated with severe acute respiratory syndrome. BMC Infect Dis 6(1):82. https://doi.org/10.1186/1471-2334-6-82

70. Linnik JE, Egli A (2016) Impact of host genetic polymorphisms on vaccine induced antibody response. Hum Vaccin Immunother 12(4):907-915. https://doi.org/10.1080/21645515.2015.1119345

71. Doyle WJ, Casselbrant ML, Li-Korotky H-S, Cullen Doyle AP, Lo C-Y, Turner R, Cohen S (2010) The interleukin 6-174 C/C genotype predicts greater rhinovirus illness. Int J Infect Dis 201(2):199-206. https://doi.org/10.1086/649559

72. Ulhaq ZS, Soraya GV (2020) Anti-IL-6 receptor antibody treatment for severe COVID-19 and the potential implication of IL-6 gene polymorphisms in novel coronavirus pneumonia. Med Clin (Barc). 155(12):548-556. https://doi.org/10.1016/j.medcli.2020. 07.002

73. Kirtipal N, Bharadwaj S (2020) Interleukin 6 polymorphisms as an indicator of COVID-19 severity in humans. J Biomol Struct Dyn. https://doi.org/10.1080/07391102.2020.1776640

74. Panda AK, Padhi A, Prusty BAK (2020) CCR5 $\Delta 32$ minorallele is associated with susceptibility to SARS-CoV-2 infection and death: an epidemiological investigation. Clin Chim Acta 510:60-61. https://doi.org/10.1016/j.cca.2020.07.012

75. Patarčić I, Gelemanović A, Kirin M, Kolčić I, Theodoratou E, Baillie KJ, De Jong MD, Rudan I, Campbell H, Polašek O (2015) The role of host genetic factors in respiratory tract infectious diseases: systematic review, meta-analyses and field synopsis. Sci Rep 5(1):1-10. https://doi.org/10.1038/srep16119

76. Novick D, Cohen B, Rubinstein M (1994) The human interferon $\alpha \beta$ receptor: characterization and molecular cloning. Cell 77(3):391-400. https://doi.org/10.1016/0092-8674(94)90154-6

77. Pairo-Castineira E, Clohisey S, Klaric L, Bretherick AD, Rawlik K, Pasko D, Walker S, Parkinson N, Fourman MH, Russell CD (2020) Genetic mechanisms of critical illness in Covid-19. Nature. https://doi.org/10.1038/s41586-020-03065-y

78. Rugwizangoga B, Andersson ME, Kabayiza J-C, Nilsson MS, Ármannsdóttir B, Aurelius J, Nilsson S, Hellstrand K, Lindh M, Martner A (2019) IFNL4 genotypes predict clearance of RNA viruses in Rwandan children with upper respiratory tract infections. Front Cell Infect Microbiol 9:340. https://doi.org/10.3389/ fcimb.2019.00340

79. Amodio E, Pipitone RM, Grimaudo S, Immordino P, Maida CM, Prestileo T, Restivo V, Tramuto F, Vitale F, Craxì A (2020) SARS-CoV-2 viral load, IFN $\lambda$ polymorphisms and the course of COVID-19: an observational study. J Clin Med 9(10):3315. https://doi.org/10.3390/jcm9103315

80. Song A, Nikolcheva T, Krensky AM (2000) Transcriptional regulation of RANTES expression in T lymphocytes. Immunol Rev 177:236-245. https://doi.org/10.1034/j.1600-065x.2000.17610.x

81. Singh SK, Mishra MK, Eltoum I-EA, Bae S, Lillard JW, Singh $\mathrm{R}$ (2018) CCR5/CCL5 axis interaction promotes migratory and 
invasiveness of pancreatic cancer cells. Sci. Rep 8(1):1-12. https://doi.org/10.1038/s41598-018-19643-0

82. Donlon T, Krensky A, Wallace MR, Collins FS, Lovett M, Clayberger C (1990) Localization of a human T-cell-specific gene, RANTES (D17S136E), to chromosome 17q11. 2-q12. Genomics 6(3):548-553. https://doi.org/10.1016/0888-7543(90)90485-d

83. Ng MW, Zhou G, Chong WP, Lee LWY, Law HKW, Zhang H, Wong WHS, Fok SFS, Zhai Y, Yung RW (2007) The association of RANTES polymorphism with severe acute respiratory syndrome in Hong Kong and Beijing Chinese. BMC Infect Dis 7(1):50. https://doi.org/10.1186/1471-2334-7-50

84. Hovnanian A, Rebouillat D, Mattei M-G, Levy ER, Marie I, Monaco AP, Hovanessian AG (1998) The human 2', 5'-oligoadenylate synthetase locus is composed of three distinct genes clustered on chromosome 12q24. 2 encoding the 100-, 69-, and 40-kDa forms. Genomics 52(3):267-277. https://doi.org/10. 1006/geno.1998.5443

85. Drappier M, Michiels T (2015) Inhibition of the OAS/RNase L pathway by viruses. Curr Opin Virol 15:19-26. https://doi.org/ 10.1016/j.coviro.2015.07.002

86. Weiss SR (2020) Activation and $* * * * * *$ antagonism of the OASRNase L pathway. Proceedings 50(1):14. https://doi.org/10.3390/ proceedings 2020050014

87. Silverman RH (2007) Viral encounters with $2^{\prime}, 5^{\prime}$-oligoadenylate synthetase and rnase 1 during the interferon antiviral response. J Virol 81(23):12720-12729. https://doi.org/10.1128/JVI. 01471-07

88. Horisberger MA, Wathelet M, Szpirer J, Szpirer C, Islam Q, Levan G, Huez G (1988) cDNA cloning and assignment to chromosome 21 of IFI-78K gene, the human equivalent of murineMx gene. Somat Cell Mol Genet 14(2):123-131. https://doi.org/10. 1007/BF01534397

89. Haller O, Staeheli P, Kochs G (2007) Interferon-induced Mx proteins in antiviral host defense. Biochimie 89(6-7):812-818. https://doi.org/10.1016/j.biochi.2007.04.015

90. He J, Feng D, de Vlas SJ, Wang H, Fontanet A, Zhang P, Plancoulaine S, Tang F, Zhan L, Yang H (2006) Association of SARS susceptibility with single nucleic acid polymorphisms of OAS1 and MxA genes: a case-control study. BMC Infect Dis 6(1):106. https://doi.org/10.1186/1471-2334-6-106

91. Cao B, Liu X, Hou F, Li W, Han Z, Zhang Q, Dai Y, Xu C, Qi H (2009) The haplotype of the MxA gene promoter is associated with hepatitis B virus infection in a Chinese population. Liver Int 29(9):1383-1388. https://doi.org/10.1111/j.1478-3231.2009. 02053.X

92. Ching JC-Y, Chan KYK, Lee EHL, Xu M-S, Ting CKP, So TM, Sham PC, Leung GM, Peiris JS, Khoo U-S (2010) Significance of the Myxovirus resistance A (MxA) gene-123C $>$ a singlenucleotide polymorphism in suppressed interferon $\beta$ induction of severe acute respiratory syndrome coronavirus infection. Int J Infect Dis 201(12):1899-1908. https://doi.org/10.1086/652799

93. Hamano E, Hijikata M, Itoyama S, Quy T, Phi NC, Long HT, Van Ban V, Matsushita I, Yanai H, Kirikae F (2005) Polymorphisms of interferon-inducible genes OAS-1 and MxA associated with SARS in the Vietnamese population. Biochem Biophys Res Commun 329(4):1234-1239. https://doi.org/10.1016/j.bbrc. 2005.02.101

94. Hijikata M, Ohta Y, Mishiro S (2000) Identification of a single nucleotide polymorphism in the MxA gene promoter (G/T at nt-88) correlated with the response of hepatitis $\mathrm{C}$ patients to interferon. Intervirology 43(2):124-127. https://doi.org/10.1159/ 000025035

95. Knapp S, Yee L, Frodsham A, Hennig B, Hellier S, Zhang L, Wright M, Chiaramonte M, Graves M, Thomas H (2003) Polymorphisms in interferon-induced genes and the outcome of hepatitis $\mathrm{C}$ virus infection: roles of MxA, OAS-1 and PKR. Genes Immun 4(6):411-419. https://doi.org/10.1038/sj.gene. 6363984

96. Kong X-F, Zhang X-X, Gong Q-M, Gao J, Zhang S-Y, Wang L, Xu J, Han Y, Jin G-D, Jiang J-H (2007) MxA induction may predict sustained virologic responses of chronic hepatitis B patients with IFN- $\alpha$ treatment. J Interferon Cytokine Res 27(9):809-818. https://doi.org/10.1089/jir.2006.0163

97. Suzuki F, Arase Y, Suzuki Y, Tsubota A, Akuta N, Hosaka T, Someya T, Kobayashi M, Saitoh S, Ikeda K (2004) Single nucleotide polymorphism of the MxA gene promoter influences the response to interferon monotherapy in patients with hepatitis $\mathrm{C}$ viral infection. J Viral Hepat 11(3):271-276. https://doi.org/10. 1111/j.1365-2893.2004.00509.x

98. Zhang X, Xu H, Chen X, Li X, Wang X, Ding S, Zhang R, Liu L, He C, Zhuang L (2014) Association of functional polymorphisms in the MxA gene with susceptibility to enterovirus 71 infection. Am J Hum Genet 133(2):187-197. https://doi.org/10. 1007/s00439-013-1367-3

99. Yuan FF, Boehm I, Chan PK, Marks K, Tang JW, Hui DS, Sung JJ, Dyer WB, Geczy AF, Sullivan JS (2007) High prevalence of the CD14-159CC genotype in patients infected with severe acute respiratory syndrome-associated coronavirus. Clin Vaccine Immunol 14(12):1644-1645. https://doi.org/10.1128/CVI. 00100-07

100. Tu X, Chong WP, Zhai Y, Zhang H, Zhang F, Wang S, Liu W, Wei M, Siu NHO, Yang H (2015) Functional polymorphisms of the CCL2 and MBL genes cumulatively increase susceptibility to severe acute respiratory syndrome coronavirus infection. J Infect 71(1):101-109. https://doi.org/10.1016/j.jinf.2015.03.006

101. Bashirova AA, Wu L, Cheng J, Martin TD, Martin MP, Benveniste RE, Lifson JD, Kewal Ramani VN, Hughes A, Carrington M (2003) Novel member of the CD209 (DC-SIGN) gene family in primates. J Virol 77(1):217-227. https://doi.org/10.1128/jvi. 77.1.217-227.2003

102. Ortiz M, Kaessmann H, Zhang K, Bashirova A, Carrington M, Quintana-Murci L, Telenti A (2008) The evolutionary history of the CD209 (DC-SIGN) family in humans and non-human primates. Genes Immun 9(6):483-492. https://doi.org/10.1038/ gene. 2008.40

103. Zhou T, Chen Y, Hao L, Zhang Y (2006) DC-SIGN and immunoregulation. Cell Mol Immunol 3(4):279-283

104. Curtis BM, Scharnowske S, Watson AJ (1992) Sequence and expression of a membrane-associated C-type lectin that exhibits CD4-independent binding of human immunodeficiency virus envelope glycoprotein gp120. Proc Natl Acad Sci USA 89(17):8356-8360. https://doi.org/10.1073/pnas.89.17.8356

105. Alvarez CP, Lasala F, Carrillo J, Muñiz O, Corbí AL, Delgado R (2002) C-type lectins DC-SIGN and L-SIGN mediate cellular entry by Ebola virus in cis and in trans. J Virol 76(13):68416844. https://doi.org/10.1128/JVI.76.13.6841-6844.2002

106. Iyer GR, Samajder S, Zubeda S, Mali V, Pv SK, Sharma A, Abbas NZ, Bora NS, Narravula A, Hasan Q (2020) Infectivity and progression of COVID19 based on selected host candidate gene variants. Front Genet 11:861. https://doi.org/10.3389/fgene. 2020.00861

107. Barkhash AV, Perelygin AA, Babenko VN, Brinton MA, Voevoda MI (2012) Single nucleotide polymorphism in the promoter region of the CD209 gene is associated with human predisposition to severe forms of tick-borne encephalitis. Antiviral Res 93(1):64-68. https://doi.org/10.1016/j.antiviral.2011.10.017

108. Chen Y, Zhao YH, Di Y-P, Wu R (2001) Characterization of human mucin $5 \mathrm{~B}$ gene expression in airway epithelium and the genomic clone of the amino-terminal and 5'-flanking region. Am 
J Respir Cell Mol Biol 25(5):542-553. https://doi.org/10.1165/ ajrcmb.25.5.4298

109. Zhang Q, Wang Y, Qu D, Yu J, Yang J (2019) The possible pathogenesis of idiopathic pulmonary fibrosis considering MUC5B. Biomed Res Int 2019:9712464. https://doi.org/10.1155/ 2019/9712464

110. Jia R, Pan Q, Ding S, Rong L, Liu S-L, Geng Y, Qiao W, Liang C (2012) The N-terminal region of IFITM3 modulates its antiviral activity by regulating IFITM3 cellular localization. J Virol 86(24):13697-13707. https://doi.org/10.1128/JVI.01828-12

111. Kamio K, Matsushita I, Hijikata M, Kobashi Y, Tanaka G, Nakata K, Ishida T, Tokunaga K, Taguchi Y, Homma S (2005) Promoter analysis and aberrant expression of the MUC5B gene in diffuse panbronchiolitis. Am J Respir Crit Care Med 171(9):949-957. https://doi.org/10.1164/rccm.200409-11680C

112. Johnson L (2010) Genetically determined variation of respiratory mucins: disease and demography. Dissertation, University College London

113. Zhao X, Li J, Winkler CA, An P, Guo J-T (2019) IFITM genes, variants, and their roles in the control and pathogenesis of viral infections. Front Microbiol 9:3228. https://doi.org/10. 3389/fmicb.2018.03228

114. Uhlenhaut NH, Jakob S, Anlag K, Eisenberger T, Sekido R, Kress J, Treier A-C, Klugmann C, Klasen C, Holter NI (2009) Somatic sex reprogramming of adult ovaries to testes by FOXL2 ablation. Cell 139(6):1130-1142. https://doi.org/ 10.1016/j.cell.2009.11.021

115. Lu S, Bevier M, Huhn S, Sainz J, Lascorz J, Pardini B, Naccarati A, Vodickova L, Novotny J, Hemminki K (2013) Genetic variants in C-type lectin genes are associated with colorectal cancer susceptibility and clinical outcome. Int J Cancer 133(10):2325-2333. https://doi.org/10.1002/ijc.28251

116. Gómez J, Albaiceta GM, Cuesta-Llavona E, García-Clemente M, López-Larrea C, Amado-Rodríguez L, López-Alonso I, Melón S, Alvarez-Argüelles ME, Gil-Peña H (2021) The Interferon-induced transmembrane protein 3 gene (IFITM3) rs $12252 \mathrm{C}$ variant is associated with COVID-19. Cytokine 137:155354. https://doi.org/10.1016/j.cyto.2020.155354

117. Bouças AP, Oliveira FdSd, Canani LH, Crispim D (2013) The role of interferon induced with helicase $\mathrm{C}$ domain 1 (IFIH1) in the development of type 1 diabetes mellitus. Arq Bras Endocrinol Metabol 57(9):667-676. https://doi.org/10.1590/s000427302013000900001

118. Maiti AK (2020) The African-American population with a low allele frequency of SNP rs1990760 (T allele) in IFIH1 predicts less IFN-beta expression and potential vulnerability to COVID-19 infection. Immunogenetics 72(6):387-391. https:// doi.org/10.1007/s00251-020-01174-6

119. Smola S, Hoth M, Zufall F (2015) Recognition of bacterial signal peptides by mammalian formyl peptide receptors. J Biol Chem 290(12):7369-7387. https://doi.org/10.1074/jbc.M114. 626747

120. Petrazzuolo A, Le Naour J, Vacchelli E, Gaussem P, Ellouze S, Jourdi G, Solary E, Fontenay M, Smadja DM, Kroemer G (2020) No impact of cancer and plague-relevant FPR1 polymorphisms on COVID-19. OncoImmunology 9(1):1857112. https://doi.org/ 10.1080/2162402X.2020.1857112

121. Zhang H, Maqsudi S, Rainczuk A, Duffield N, Lawrence J, Keane FM, Justa-Schuch D, Geiss-Friedlander R, Gorrell MD, Stephens AN (2015) Identification of novel dipeptidyl peptidase 9 substrates by two-dimensional differential in-gel electrophoresis. FEBS J 282(19):3737-3757. https://doi.org/10.1111/febs.13371

122. Geiss-Friedlander R, Parmentier N, Möller U, Urlaub H, Van den Eynde BJ, Melchior F (2009) The cytoplasmic peptidase DPP9 is rate-limiting for degradation of proline-containing peptides. $\mathrm{J}$.
Biol. Chem 284(40):27211-27219. https://doi.org/10.1074/jbc. M109.041871

123. Griswold AR, Ball DP, Bhattacharjee A, Chui AJ, Rao SD, Taabazuing CY, Bachovchin DA (2019) DPP9's enzymatic activity and not its binding to CARD8 inhibits inflammasome activation. ACS Chem Biol 14(11):2424-2429. https://doi.org/ 10.1021/acschembio.9b00462

124. Fingerlin TE, Murphy E, Zhang W, Peljto AL, Brown KK, Steele MP, Loyd JE, Cosgrove GP, Lynch D, Groshong S (2013) Genome-wide association study identifies multiple susceptibility loci for pulmonary fibrosis. Nat Genet 45(6):613-620. https://doi. org/10.1038/ng.2609

125. Mahdi BM (2019) Introductory chapter: concept of human leukocyte antigen (HLA). human leukocyte antigen (HLA). IntechOpen, London, pp 1-8

126. Keicho N, Itoyama S, Kashiwase K, Phi NC, Long HT, Van Ban V, Hoa BK, Le Hang NT, Hijikata M, Sakurada S (2009) Association of human leukocyte antigen class II alleles with severe acute respiratory syndrome in the Vietnamese population. Hum Immunol 70(7):527-531. https://doi.org/10.1016/j.humimm. 2009.05.006

127. Chen Y-MA, Liang S-Y, Shih Y-P, Chen C-Y, Lee Y-M, Chang L, Jung S-Y, Ho M-S, Liang K-Y, Chen H-Y (2006) Epidemiological and genetic correlates of severe acute respiratory syndrome coronavirus infection in the hospital with the highest nosocomial infection rate in Taiwan in 2003. Clin Microbiol Infect 44(2):359-365. https://doi.org/10.1128/JCM.44.2.359-365.2006

128. Wang S-F, Chen K-H, Chen M, Li W-Y, Chen Y-J, Tsao C-H, Yen M-Y, Huang JC, Chen Y-MA (2011) Human-leukocyte antigen class I Cw 1502 and class II DR 0301 genotypes are associated with resistance to severe acute respiratory syndrome (SARS) infection. Viral Immunol 24(5):421-426. https://doi.org/10.1089/ vim.2011.0024

129. Hajeer AH, Balkhy H, Johani S, Yousef MZ, Arabi Y (2016) Association of human leukocyte antigen class II alleles with severe Middle East respiratory syndrome-coronavirus infection. Ann Thorac Med 11(3):211. https://doi.org/10.4103/1817-1737. 185756

130. Amoroso A, Magistroni P, Vespasiano F, Bella A, Bellino S, Puoti F, Alizzi S, Vaisitti T, Boros S, Grossi PA (2021) HLA and AB0 polymorphisms may influence SARS-CoV-2 infection and COVID-19 severity. Transplantation 105(1):193-200. https://doi. org/10.1097/TP.0000000000003507

131. Siddiq A, Lepretre F, Hercberg S, Froguel P, Gibson F (2005) A synonymous coding polymorphism in the $\alpha 2$-Heremans-Schmid glycoprotein gene is associated with type 2 diabetes in French Caucasians. Diabetes 54(8):2477-2481. https://doi.org/10.2337/ diabetes.54.8.2477

132. Mori K, Emoto M, Inaba M (2011) Fetuin-A: a multifunctional protein. Recent Pat Endocr Metab Immune Drug Discov 5(2):124-146. https://doi.org/10.2174/187221411799015372

133. Osawa M, Yuasa I, Kitano T, Henke J, Kaneko M, Udono T, Saitou N, Umetsu K (2001) Haplotype analysis of the human


34. https://doi.org/10.1046/j.1469-1809.2001.6510027.x

134. Bourebaba L, Marycz K (2019) Pathophysiological implication of Fetuin-A glycoprotein in the development of metabolic disorders: a concise review. J Clin Med 8(12):2033. https://doi.org/ $10.3390 / \mathrm{jcm} 8122033$

135. Lebreton J, Joisel F, Raoult J, Lannuzel B, Rogez J, Humbert G (1979) Serum concentration of human alpha 2 HS glycoprotein during the inflammatory process: evidence that alpha 2 HS glycoprotein is a negative acute-phase reactant. J Clin Invest 64(4):1118-1129. https://doi.org/10.1172/JCI109551

136. Ombrellino $M$, Wang $H$, Yang $H$, Zhang $M$, Vishnubhakat $J$, Frazier A, Scher LA, Friedman SG, Tracey KJ (2001) Fetuin, a 
negative acute phase protein, attenuates TNF synthesis and the innate inflammatory response to carrageenan. Shock 15(3):181185. https://doi.org/10.1097/00024382-200115030-00004

137. Zhu X, Wang Y, Zhang H, Liu X, Chen T, Yang R, Shi Y, Cao W, Li P, Ma Q (2011) Genetic variation of the human $\alpha-2$ Heremans-Schmid glycoprotein (AHSG) gene associated with the risk of SARS-CoV infection. PLoS ONE 6(8):e23730. https:// doi.org/10.1371/journal.pone.0023730

138. Butini L, De Fougerolles AR, Vaccarezza M, Graziosi C, Cohen DI, Montroni M, Springer TA, Pantaleo G, Fauci AS (1994) Intercellular adhesion molecules (ICAM)-1 ICAM-2 and ICAM-3 function as counter-receptors for lymphocyte function-associated molecule 1 in human immunodeficiency virusmediated syncytia formation. Eur J Immunol 24(9):2191-2195. https://doi.org/10.1002/eji.1830240939

139. Chan KY, Ching JC, Xu M, Cheung AN, Yip S-P, Yam LY, Lai S-T, Chu C-M, Wong AT, Song Y-Q (2007) Association of ICAM3 genetic variant with severe acute respiratory syndrome. Int J Infect Dis 196(2):271-280. https://doi.org/10.1086/518892

140. Teimouri H, Maali A (2020) Single-Nucleotide polymorphisms in host pattern-recognition receptors show association with antiviral responses against SARS-CoV-2, in-silico trial. JoMMID 8(2):65-70

141. Karcioglu Batur L, Hekim N (2020) The role of DBP gene polymorphisms in the prevalence of new coronavirus disease 2019 infection and mortality rate. J Med Virol 93:1409-1413. https://doi.org/10.1002/jmv.26409

142. Bikle DD, Schwartz J (2019) Vitamin D binding protein, total and free vitamin D levels in different physiological and pathophysiological conditions. Front Endocrinol (Lausanne) 10:317. https://doi.org/10.3389/fendo.2019.00317

143. Xie C-N, Yue M, Huang P, Tian T, Fan H-Z, Wu M-P, Yu R-B, Yi H-G, Xia X-S, Feng Y (2018) Vitamin D binding protein polymorphisms influence susceptibility to hepatitis $\mathrm{C}$ virus infection in a high-risk Chinese population. Gene 679:405411. https://doi.org/10.1016/j.gene.2018.09.021

144. Mehramiz M, Khayyatzadeh SS, Esmaily H, Ghasemi F, Sadeghi-Ardekani K, Tayefi M, Mirmousavi SJ, Hanachi P, Bahrami-Taghanaki H, Eslami S (2019) Associations of vitamin D binding protein variants with the vitamin D-induced increase in serum 25-hydroxyvitamin D. Clin Nutr ESPEN 29:59-64. https://doi.org/10.1016/j.clnesp.2018.12.005

145. Beecham GW, Martin ER, Li Y-J, Slifer MA, Gilbert JR, Haines JL, Pericak-Vance MA (2009) Genome-wide association study implicates a chromosome 12 risk locus for late-onset Alzheimer disease. Am J Hum Genet 84(1):35-43. https://doi. org/10.1016/j.ajhg.2008.12.008

146. Carlberg C, Campbell MJ (2013) Vitamin D receptor signaling mechanisms: integrated actions of a well-defined transcription factor. Steroids 78(2):127-136. https://doi.org/10.1016/j.stero ids.2012.10.019

147. Pike JW, Meyer MB (2012) The vitamin D receptor: new paradigms for the regulation of gene expression by 1,25-dihydroxyvitamin D3. Rheum Dis Clin N Am 38(1):13-27. https:// doi.org/10.1016/j.ecl.2010.02.007

148. Khammissa R, Fourie J, Motswaledi M, Ballyram R, Lemmer J, Feller L (2018) The biological activities of vitamin D and its receptor in relation to calcium and bone homeostasis, cancer, immune and cardiovascular systems, skin biology, and oral health. Biomed Res Int 2018:9276380. https://doi.org/10.1155/ 2018/9276380

149. Christakos S, Dhawan P, Verstuyf A, Verlinden L, Carmeliet G (2016) Vitamin D: metabolism, molecular mechanism of action, and pleiotropic effects. Physiol Rev Suppl 96(1):365408. https://doi.org/10.1152/physrev.00014.2015
150. Rosen CJ, Adams JS, Bikle DD, Black DM, Demay MB, Manson JE, Murad MH, Kovacs CS (2012) The nonskeletal effects of vitamin D: an Endocrine Society scientific statement. Endocr Rev 33(3):456-492. https://doi.org/10.1210/er. 2012-1000

151. Cantorna MT, Snyder L, Lin Y-D, Yang L (2015) Vitamin D and 1, $25(\mathrm{OH}) 2 \mathrm{D}$ regulation of T cells. Nutrients 7(4):3011-3021. https://doi.org/10.3390/nu7043011

152. Wei R, Christakos S (2015) Mechanisms underlying the regulation of innate and adaptive immunity by vitamin D. Nutrients 7(10):8251-8260. https://doi.org/10.3390/nu7105392

153. Laplana M, Royo JL, Fibla J (2018) Vitamin D Receptor polymorphisms and risk of enveloped virus infection: a meta-analysis. Gene 678:384-394. https://doi.org/10.1016/j.gene.2018.08. 017

154. Grant WB, Lahore H, McDonnell SL, Baggerly CA, French CB, Aliano JL, Bhattoa HP (2020) Evidence that vitamin D supplementation could reduce risk of influenza and COVID-19 infections and deaths. Nutrients 12(4):988. https://doi.org/10.3390/ nu12040988

155. Brocchieri L, De Macario EC, Macario AJ (2008) hsp70 genes in the human genome: Conservation and differentiation patterns predict a wide array of overlapping and specialized functions. BMC Evol Biol 8(1):19. https://doi.org/10.1186/ 1471-2148-8-19

156. Wang R, Qin H-M, Qin L, Wei J-X, Wei Y-X, Wang J-L (2019) Genetic association of promoter in GRP78 gene with nasopharyngeal carcinoma in a Chinese population. Int J Clin Oncol 24(4):359-365. https://doi.org/10.1007/s10147-018-1366-4

157. Ha DP, Van Krieken R, Carlos A, Lee AS (2020) The stressinducible molecular chaperone GRP78 as potential therapeutic target for Coronavirus infection. J Infect 81(3):452-482. https://doi.org/10.1016/j.jinf.2020.06.017

158. Ibrahim IM, Abdelmalek DH, Elshahat ME, Elfiky AA (2020) COVID-19 spike-host cell receptor GRP78 binding site prediction. J Infect 80(5):554-562. https://doi.org/10.1016/j.jinf. 2020.02.026

159. Liu S, Li K, Li T, Xiong X, Yao S, Chen Z, Wang C, Zhao B (2013) Association between promoter polymorphisms of the GRP78 gene and risk of type 2 diabetes in a Chinese Han population. DNA Cell Biol. 32(3):119-124. https://doi.org/10. 1089/dna.2012.1909

160. Muramatsu T (2012) Basigin: a multifunctional membrane protein with an emerging role in infections by malaria parasites. Expert Opin Ther Targets 16(10):999-1011. https://doi.org/10. 1517/14728222.2012.711818

161. Kasinrerk W, Fiebiger E, Stefanova I, Baumruker T, Knapp W, Stockinger H (1992) Human leukocyte activation antigen M6, a member of the Ig superfamily, is the species homologue of rat OX-47, mouse basigin, and chicken HT7 molecule. J Immunol Res 149(3):847-854

162. Iacono KT, Brown AL, Greene MI, Saouaf SJ (2007) CD147 immunoglobulin superfamily receptor function and role in pathology. Exp Mol Pathol 83(3):283-295. https://doi.org/10. 1016/j.yexmp.2007.08.014

163. Fossum SR, Mallett S, Neil Barclay A (1991) The MRC OX-47 antigen is a member of the immunoglobulin superfamily with an unusual transmembrane sequence. Eur J Immunol 21(3):671-679. https://doi.org/10.1002/eji.1830210320

164. DeCastro R, Zhang Y, Guo H, Kataoka H, Gordon MK, Toole BP, Biswas C (1996) Human keratinocytes express EMMPRIN, an extracellular matrix metalloproteinase inducer. J Invest Dermatol 106(6):1260-1265. https://doi.org/10.1111/1523-1747. ep12348959

165. Nehme CL, Fayos BE, Bartles JR (1995) Distribution of the integral plasma membrane glycoprotein CE9 (MRC OX-47) 
among rat tissues and its induction by diverse stimuli of metabolic activation. Biochem J 310(2):693-698. https://doi.org/ 10.1042/bj3100693

166. Agrawal SM, Silva C, Wang J, Tong JP-W, Yong VW (2012) A novel anti-EMMPRIN function-blocking antibody reduces $\mathrm{T}$ cell proliferation and neurotoxicity: relevance to multiple sclerosis. J. Neuroinflammation 9(1):1-14

167. Sato M, Nakai Y, Nakata W, Yoshida T, Hatano K, Kawashima A, Fujita K, Uemura M, Takayama H, Nonomura N (2013) EMMPRIN promotes angiogenesis, proliferation, invasion and resistance to sunitinib in renal cell carcinoma, and its level predicts patient outcome. PLoS ONE 8(9):e74313. https://doi. org/10.1371/journal.pone.0074313

168. Xiong L, Edwards CK, Zhou L (2014) The biological function and clinical utilization of CD147 in human diseases: a review of the current scientific literature. Int J Mol Sci 15(10):1741117441. https://doi.org/10.3390/ijms151017411

169. Yurchenko V, Constant S, Eisenmesser E, Bukrinsky M (2010) Cyclophilin-CD147 interactions: a new target for anti-inflammatory therapeutics. Clin Exp Immunol 160(3):305-317. https://doi.org/10.1111/j.1365-2249.2010.04115.x

170. Landskron J, Taskén K (2013) CD147 in regulatory T cells. Cell Immunol 282(1):17-20. https://doi.org/10.1016/j.cellimm.2013. 04.008

171. Yan J, Mao Y, Wang C, Wang Z (2015) Association study between an SNP in CD147 and its expression with acute coronary syndrome in a Jiangsu Chinese population. Medicine. https://doi.org/10.1097/MD.0000000000001537

172. Pushkarsky T, Zybarth G, Dubrovsky L, Yurchenko V, Tang H, Guo H, Toole B, Sherry B, Bukrinsky M (2001) CD147 facilitates HIV-1 infection by interacting with virus-associated cyclophilin A. Proc Natl Acad Sci USA 98(11):6360-6365. https://doi. org/10.1073/pnas.111583198

173. Chen Z, Mi L, Xu J, Yu J, Wang X, Jiang J, Xing J, Shang P, Qian A, Li Y (2005) Function of HAb18G/CD147 in invasion of host cells by severe acute respiratory syndrome coronavirus. Int J Infect Dis 191(5):755-760. https://doi.org/10.1086/427811

174. Watanabe A, Yoneda M, Ikeda F, Terao-Muto Y, Sato H, Kai C (2010) CD147/EMMPRIN acts as a functional entry receptor for measles virus on epithelial cells. J Virol 84(9):4183-4193. https://doi.org/10.1128/JVI.02168-09

175. Jin W, Wu W, Yang K, Shen F, Fu N, Feng Y, Fu Y (2020) The single nucleotide polymorphisms of chromosome 9p21 and CD147 were relevant with the carotid plaque risk in acute cerebral infarction patients among Chinese Han population. J Mol Neurosci. https://doi.org/10.1007/s12031-020-01540-9

176. Zhou J, Song B, Duan X, Long Y, Lu J, Li Z, Zeng S, Zhan Q, Yuan M, Yang Q (2014) Association of BSG genetic polymorphisms with atherosclerotic cerebral infarction in the Han Chinese population. Int J Neurol 124(10):734-740. https://doi. org/10.3109/00207454.2013.877461

177. Hu X, Su J, Zhou Y, Xie X, Peng C, Yuan Z, Chen X (2017) Repressing CD147 is a novel therapeutic strategy for malignant melanoma. Oncotarget 8(15):25806. https://doi.org/10.18632/ oncotarget. 15709

178. Wu L-S, Li F-F, Sun L-D, Li D, Su J, Kuang Y-H, Chen G, Chen X-P, Chen X (2011) A miRNA-492 binding-site polymorphism in BSG (basigin) confers risk to psoriasis in central south Chinese population. Hum Genet 130(6):749-757. https://doi.org/10. 1007/s00439-011-1026-5

179. Wang K, Chen W, Zhang Z, Deng Y, Lian J-Q, Du P, Wei D, Zhang Y, Sun X-X, Gong L (2020) CD147-spike protein is a novel route for SARS-CoV-2 infection to host cells. Signal Transduct Target Ther 5(1):1-10. https://doi.org/10.1038/ s41392-020-00426-x
180. Lambeir A-M, Durinx C, Scharpé S, De Meester I (2003) Dipeptidyl-peptidase IV from bench to bedside: an update on structural properties, functions, and clinical aspects of the enzyme DPP IV. Crit Rev Clin Lab Sci 40(3):209-294. https://doi.org/10.1080/ 713609354

181. Wang N, Shi X, Jiang L, Zhang S, Wang D, Tong P, Guo D, Fu L, Cui Y, Liu X (2013) Structure of MERS-CoV spike receptorbinding domain complexed with human receptor DPP4. Cell Res 23(8):986-993. https://doi.org/10.1038/cr.2013.92

182. Cantuti-Castelvetri L, Ojha R, Pedro LD, Djannatian M, Franz J, Kuivanen S, van der Meer F, Kallio K, Kaya T, Anastasina M (2020) Neuropilin-1 facilitates SARS-CoV-2 cell entry and infectivity. Science 370(6518):856-860. https://doi.org/10.1126/ science.abd2985

183. Davies J, Randeva H, Chatha K, Hall M, Spandidos D, Karteris E, Kyrou E (2020) Neuropilin-1 as a new potential SARS-CoV-2 infection mediator implicated in the neurologic features and central nervous system involvement of COVID-19. Mol Med Rep 22:4221-4226. https://doi.org/10.3892/mmr.2020.11510

184. He Z, Tessier-Lavigne M (1997) Neuropilin is a receptor for the axonal chemorepellent Semaphorin III. Cell 90(4):739-751. https://doi.org/10.1016/s0092-8674(00)80534-6

185. Moses KM, Klagsbrun M (1999) Molecular angiogenesis. Chem Biol 6:R217-224. https://doi.org/10.1016/S1074-5521(99) 80081-7

186. Mayi BS, Leibowitz JA, Woods AT, Ammon KA, Liu AE, Raja A (2021) The role of Neuropilin-1 in COVID-19. PLoS Pathog. 17(1):e1009153. https://doi.org/10.1371/journal.ppat.1009153

187. Coutard B, Valle C, de Lamballerie X, Canard B, Seidah N, Decroly E (2020) The spike glycoprotein of the new coronavirus 2019-nCoV contains a furin-like cleavage site absent in $\mathrm{CoV}$ of the same clade. Antiviral Res 176:104742. https://doi.org/10. 1016/j.antiviral.2020.104742

188. Longping VT, Hamilton AM, Friling T, Whittaker GR (2014) A novel activation mechanism of avian influenza virus H9N2 by furin. J Virol 88(3):1673-1683. https://doi.org/10.1128/JVI. 02648-13

189. Hwang JY, Sun Y, Carroll CR, Usherwood EJ (2019) Neuropilin-1 regulates the secondary CD8 $\mathrm{T}$ cell response to virus infection. mSphere 4(3):e00221-e319. https://doi.org/10.1128/ mSphere.00221-19

190. Fan S-H, Shen Z-Y, Xiao Y-M (2018) Functional polymorphisms of the neuropilin 1 gene are associated with the risk of tetralogy of Fallot in a Chinese Han population. Gene 653:72-79. https:// doi.org/10.1016/j.gene.2018.02.027

191. Agúndez JA, García-Martín E, Martínez C, Benito-León J, Millán-Pascual J, Díaz-Sánchez M, Calleja P, Pisa D, Turpín-Fenoll L, Alonso-Navarro H (2016) Heme oxygenase-1 and 2 common genetic variants and risk for multiple sclerosis. Sci Rep 6(1):1-7

192. Fakhouri EW, Peterson SJ, Kothari J, Alex R, Shapiro JI, Abraham NG (2020) Genetic polymorphisms complicate COVID-19 therapy: pivotal role of HO-1 in cytokine storm. Antioxidants 9(7):636. https://doi.org/10.3390/antiox9070636

193. Arutyunov GP, Koziolova NA, Tarlovskaya EI, Arutyunov AG, Grigorjeva NY, Dzhunusbekova GA, Malchikova SV, Mitkovskaya NP, Orlova YA, Petrova MM et al (2020) The Agreed Experts' Position of the Eurasian Association of Therapists on Some new Mechanisms of COVID-19 Pathways: focus on hemostasis, hemotransfusion issues and blood gas exchange. Kardiologiia 60(5):9-19. https://doi.org/10.18087/cardio.2020.5. n1132

194. Abraham NG, Kappas A (2008) Pharmacological and clinical aspects of heme oxygenase. Pharmacol Rev 60(1):79-127. https://doi.org/10.1124/pr.107.07104

195. Radhakrishnan N, Yadav SP, Sachdeva A, Pruthi PK, Sawhney S, Piplani T, Wada T, Yachie A (2011) Human heme oxygenase-1 
deficiency presenting with hemolysis, nephritis, and asplenia. J Pediatr Hematol Oncol 33(1):74-78. https://doi.org/10.1097/ MPH.0b013e3181fd2aae

196. Hooper PL (2020) COVID-19 and heme oxygenase: novel insight into the disease and potential therapies. Cell Stress Chaperones 25(5):707-710. https://doi.org/10.1007/s12192-020-01126-9

197. Pechlaner R, Willeit P, Summerer M, Santer P, Egger G, Kronenberg F, Demetz E, Weiss G, Tsimikas S, Witztum JL (2015) Heme oxygenase-1 gene promoter microsatellite polymorphism is associated with progressive atherosclerosis and incident cardiovascular disease. Arterioscler Thromb Vasc Biol 35(1):229236. https://doi.org/10.1161/ATVBAHA.114.304729

198. Yamada N, Yamaya M, Okinaga S, Nakayama K, Sekizawa K, Shibahara S, Sasaki H (2000) Microsatellite polymorphism in the heme oxygenase-1 gene promoter is associated with susceptibility to emphysema. Am J Hum Genet 66(1):187-195. https://doi. org/10.1086/302729

199. Okamoto I, Krögler J, Endler G, Kaufmann S, Mustafa S, Exner M, Mannhalter C, Wagner O, Pehamberger H (2006) A microsatellite polymorphism in the heme oxygenase- 1 gene promoter is associated with risk for melanoma. Int J Cancer 119(6):13121315. https://doi.org/10.1002/ijc.21937

200. Hirai H, Kubo H, Yamaya M, Nakayama K, Numasaki M, Kobayashi S, Suzuki S, Shibahara S, Sasaki H (2003) Microsatellite polymorphism in heme oxygenase- 1 gene promoter is associated with susceptibility to oxidant-induced apoptosis in lymphoblastoid cell lines. Blood 102(5):1619-1621. https://doi.org/10.1182/ blood-2002-12-3733

201. Guenegou A, Leynaert B, Benessiano J, Pin I, Demoly P, Neukirch F, Boczkowski J, Aubier M (2006) Association of lung function decline with the heme oxygenase-1 gene promoter microsatellite polymorphism in a general population sample. Results from the European Community Respiratory Health Survey (ECRHS), France. Am J Med Genet A 43(8):e43-e43. https://doi.org/10.1136/jmg.2005.039743

202. Bao W, Song F, Li X, Rong S, Yang W, Wang D, Xu J, Fu J, Zhao Y, Liu L (2010) Association between heme oxygenase-1 gene promoter polymorphisms and type 2 diabetes mellitus: a HuGE review and meta-analysis. Am J Epidemiol 172(6):631-636. https://doi.org/10.1093/aje/kwq162

203. Exner M, Minar E, Wagner O, Schillinger M (2004) The role of heme oxygenase-1 promoter polymorphisms in human disease. Free Radic Biol Med 37:1097-1104. https://doi.org/10.1016/j. freeradbiomed.2004.07.008

204. Freedman BI, Kopp JB, Langefeld CD, Genovese G, Friedman DJ, Nelson GW, Winkler CA, Bowden DW, Pollak MR (2010) The apolipoprotein L1 (APOL1) gene and nondiabetic nephropathy in African Americans. J Am Soc Nephrol 21(9):1422-1426. https://doi.org/10.1681/ASN.2010070730

205. Vanhollebeke B, Pays E (2010) The trypanolytic factor of human serum: many ways to enter the parasite, a single way to kill. Mol Microbiol 76(4):806-814. https://doi.org/10.1111/j.1365-2958. 2010.07156.x

206. Shiflett AM, Bishop JR, Pahwa A, Hajduk SL (2005) Human high density lipoproteins are platforms for the assembly of multi-component innate immune complexes. J Biol Chem 280(38):32578-32585. https://doi.org/10.1074/jbc.M503510200

207. Smith EE, Malik HS (2009) The apolipoprotein L family of programmed cell death and immunity genes rapidly evolved in primates at discrete sites of host-pathogen interactions. Genome Res 19(5):850-858. https://doi.org/10.1101/gr.085647.108

208. Liu Z, Lu H, Jiang Z, Pastuszyn A, Chien-an AH (2005) Apolipoprotein L6, a novel proapoptotic Bcl-2 homology 3-only protein, induces mitochondria-mediated apoptosis in cancer cells. Mol Cancer Res 3(1):21-31

209. Zhaorigetu S, Yang Z, Toma I, McCaffrey TA, Hu C-AA (2011) Apolipoprotein L6, induced in atherosclerotic lesions, promotes apoptosis and blocks Beclin 1-dependent autophagy in atherosclerotic cells. J Biol Chem 286(31):27389-27398. https://doi. org/10.1074/jbc.M110.210245

210. Wan G, Zhaorigetu S, Liu Z, Kaini R, Jiang Z, Chien-an AH (2008) Apolipoprotein L1, a novel Bcl-2 homology domain 3 -only lipid-binding protein, induces autophagic cell death. J Biol Chem 283(31):21540-21549. https://doi.org/10.1074/jbc. M800214200

211. Zhaorigetu S, Wan G, Kaini R, Wan G, Jiang Z, C-aA Hu (2008) ApoL1, a BH3-only lipid-binding protein, induces autophagic cell death. Autophagy 4(8):1079-1082. https://doi.org/10.4161/ auto.7066

212. Couturier A, Ferlicot S, Chevalier K, Guillet M, Essig M, Jauréguiberry S, Collarino R, Dargelos M, Michaut A, Geri G (2020) Indirect effects of severe acute respiratory syndrome coronavirus 2 on the kidney in coronavirus disease patients. Clin Nephrol 13(3):347-353. https://doi.org/10.1093/ckj/sfaa088

213. Larsen C, Bourne T, Wilson J (2020) Collapsing glomerulopathy in a patient with coronavirus disease 2019 (COVID-19). Kidney Int Rep 5(6):935-939. https://doi.org/10.1016/j.ekir.2020.04.002

214. Peleg Y, Kudose S, D’Agati V, Siddall E, Ahmad S, Nickolas T, Kisselev S, Gharavi A, Canetta P (2020) Acute kidney injury due to collapsing glomerulopathy following COVID-19 infection. Kidney Int Rep 5(6):940-945. https://doi.org/10.1016/j.ekir. 2020.04.017

215. Patillon B, Luisi P, Blanche H, Patin E, Cann HM, Genin E, Sabbagh A (2012) Positive selection in the chromosome 16 VKORC1 genomic region has contributed to the variability of anticoagulant response in humans. PLoS ONE 7(12):e53049. https://doi.org/10.1371/journal.pone.0053049

216. Ross KA, Bigham AW, Edwards M, Gozdzik A, Suarez-Kurtz G, Parra EJ (2010) Worldwide allele frequency distribution of four polymorphisms associated with warfarin dose requirements. J Hum Genet 55(9):582-589. https://doi.org/10.1038/jhg.2010.73

217. Janssen R, Walk J (2020) Vitamin K epoxide reductase complex subunit 1 (VKORC1) gene polymorphism as determinant of differences in Covid-19-related disease severity. Med Hypotheses 144:110218. https://doi.org/10.1016/j.mehy.2020.110218

218. Yamamoto F, Yamamoto M, Muñiz-Diaz E (2020) Blood group ABO polymorphism inhibits SARS-CoV-2 infection and affects COVID-19 progression. Vox Sang 116(1):15-17. https://doi.org/ 10.1111/vox.13004

219. Group SC-G (2020) Genomewide association study of severe Covid-19 with respiratory failure. N Engl J Med 383(16):15221534. https://doi.org/10.1056/NEJMoa2020283

Publisher's Note Springer Nature remains neutral with regard to jurisdictional claims in published maps and institutional affiliations. 